Portland State University

PDXScholar

\title{
Why the Gender of Traditional Authorities Matters: Intersectionality and Women's Rights Advocacy in Malawi
}

\author{
Ragnhild L. Muriaas \\ University of Bergen \\ Vibeke Wang \\ Chr. Michelsen Institute \\ Lindsay J. Benstead \\ Portland State University, benstead@pdx.edu \\ Boniface Dulani \\ University of Malawi
}

Follow this and additional works at: https://pdxscholar.library.pdx.edu/polisci_fac

Part of the Feminist, Gender, and Sexuality Studies Commons, and the Political Science Commons Let us know how access to this document benefits you.

\footnotetext{
Citation Details

Published as: Muriaas, R. L., Wang, V., Benstead, L., Dulani, B., \& Rakner, L. (2019). Why the Gender of Traditional Authorities Matters: Intersectionality and Women's Rights Advocacy in Malawi. Comparative Political Studies, 52(12), 1881-1924. https://doi.org/10.1177/0010414018774369
}

This Post-Print is brought to you for free and open access. It has been accepted for inclusion in Political Science Faculty Publications and Presentations by an authorized administrator of PDXScholar. Please contact us if we can make this document more accessible: pdxscholar@pdx.edu. 


\title{
Why the Gender of Traditional Authorities Matters: Intersectionality and Women's Rights Advocacy in Malawi
}

\author{
Ragnhild L. Muriaas \\ Professor in Comparative Politics, \\ University of Bergen \\ Associated Senior Researcher, Chr. Michelsen Institute, Norway. \\ ragnhild.muriaas@uib.no
}

Vibeke Wang,

Researcher,

Chr. Michelsen Institute, Norway

vibeke.wang@cmi.no

Lindsay Benstead, Associate Professor of Political Science, Mark O. Hatfield School of Government, Portland State University benstead@pdx.edu

Boniface Dulani, Senior Lecturer, Department of Political and Administrative Studies, University of Malawi. ntwee2002@gmail.com 


\author{
Lise Rakner, \\ Professor in Comparative Politics, \\ University of Bergen \\ Senior Researcher, Chr. Michelsen Institute, Norway \\ lise.rakner@uib.no
}

\begin{abstract}
Authors' Note
Special thanks to Adam Harris, Kristen Kao, Ellen Lust, Atusaye Zgambo, and the team of enumerators from the Institute of Public Opinion and Research Malawi for their collaboration on the survey. The authors gratefully acknowledge the Program on Governance and Local Development (GLD) at the University of Gothenburg and Yale University. The LGPI Malawi survey was funded by the Swedish Research Council Grant Number 439201438 (award granted to Pam Fredman, Rector of the University of Gothenburg) and the Research Council of Norway Grant Number 233803. We thank Vegard Vibe, Steinar Askvik, Ishtiaq Jamil, Kate Baldwin, Katharina Holzinger, Melani Cammett, Eric Arias, Adam Harris, Ellen Lust, and participants at the 2016 American Political Science Association annual meeting for helpful comments. We thank Ethan Snyder and Andrew Tanner for research assistance. All remaining errors are the authors'.
\end{abstract}




\begin{abstract}
Traditional leadership often coexists with modern political institutions, yet we know little about how traditional and state authority cues — or those from male or female sources — affect public opinion. Using an original survey experiment of 1,381 Malawians embedded in the 2016 Local Governance Performance Index (LGPI), we randomly assign respondents into one of four treatment groups or a control group to hear messages about a child marriage reform from a female or male traditional authority (TA) or parliamentarian. In the sample as a whole, the female TA is as effective as the control (i.e., no endorsement), while other messengers elicit lower support (i.e., backfire effects). Endorsements produce heterogeneous effects across respondent sex and patrilineal/matrilineal customs, suggesting the need for tailored programs. Our analysis adds an intersectional approach to the governance literature, suggesting a theoretical framework that enables us to explain the impact of state and traditional endorsements across policy domains.
\end{abstract}

Keywords: Traditional authorities * Gender * Policy advocacy * Malawi * Africa * Child marriage 


\section{Introduction}

How and why do authority type and gender shape citizen's acceptance of women’s rights reforms? International agents increasingly see traditional leaders as partners in development (Baldwin, 2016), enlisting them as advocates for legal reforms which curb gender discriminating practices, such as setting a minimum age of marriage (Muriaas et al., 2018). Earlier research saw traditional authorities (TAs) as antithetical to women’s rights (Charrad, 2001; Hudson et al, 2015). Increasingly, however, development practitioners suggest that it is necessary not only to engage activists, but also to compel accountability from dominant social agents (Toyo, 2006). These strategies are based on studies demonstrating that traditional leaders are highly respected and play a major role in African contemporary politics (Logan, 2009),

Yet, despite the growing recognition about the importance of TAs as partners for development, we know little about whether traditional leaders, considered key custodians of culture (Charrad, 2001; Englebert, 2000), are effective promoters of women's rights issues among common citizens. Moreover, the answer may depend on the leader's gender in some important ways. While men have greater authority, due to their predominance in positions of power (Eagly and Karau, 2002), this assumption may not hold for gender rights—a policy domain associated with female competencies. For instance, there is considerable evidence, drawn from the gender and politics literature and role congruity theory, that citizens expect female leaders to prioritize and excel in matters relating to health, education, and women’s rights (Lawless, 2004; Huddy and Terkildsen, 1993; Rosenwasser and Seale, 1988). Their role in this regard may simply be seen as more acceptable than that of engaging in other more traditionally 
male-oriented policy domains (Eagly and Karau, 2002). ${ }^{1}$ Yet, authority gender, as well as authority institution — whether state or traditional authorities—-have seldom been considered in connection with policy advocacy.

This article draws on insights from several literatures and develops expectations about the role of traditional and state authorities in shaping citizens' attitudes about child marriage reform—a gendered human right. ${ }^{2}$ As noted, the emerging literature on governance and traditional leadership suggests that traditional leaders may have a greater capacity to organize and broker responses to rural problems than elected politicians (Cammack et al., 2009; DíazCayeros et al., 2014; Baldwin, 2016), although we still need more research to unpack how and why this is the case. We contribute to and extend these ongoing discussions by testing whether traditional leaders have a more positive effect on policy advocacy for human rights reform than elected officials. Few studies examine TAs’ effectiveness as public opinion influencers and to our knowledge, ours is the first to examine the impact of female TAs specifically. For instance, a study by Bush and Jamal (2015) shows that although most Jordanians report favorable attitudes about imams, endorsements by religious authorities do not improve support for women’s representation. Bush and Jamal's study does not, however, differentiate authorities by gender.

\footnotetext{
${ }^{1}$ Briefly, gender role congruity theory argues that prejudice against female leaders arises from the incongruity between traits associated with the female gender roles (e.g., that women are nurturing) and leadership roles (e.g., decisiveness), which are based on leaders of the past, who are often men (Eagly and Karau, 2002).

${ }^{2}$ Child marriage is regarded as a women's rights issue because the practice has grave implications for women’s health, education, and economy (see Toyo, 2006).
} 
Moreover, Benstead et al. (2015) examine the electability of female and religious candidates, but do not look at their impact as public opinion influencers, even though this is an important and overlooked form of symbolic representation (Bauer, 2016). ${ }^{3}$ Clayton (2014) is the only scholar to argue that gender may matter across authority type. Her work in Lesotho suggests that traditional leaders have less power when they are elected in local electoral divisions that are reserved for women.

So too, the gender and politics literature places substantial emphasis on how female leaders shape agendas and influence political outcomes (Bauer, 2012; Franceschet et al., 2012; Tamale, 1999; Wang, 2013). Still, this research focuses almost entirely on state actors, such as parliamentarians (MPs) and cabinet ministers, and does not examine the role of leaders' gender in their governance effectiveness. Analyses of how female MPs shape attitudes and a focus on gendered aspects of traditional leadership is missing. This gap exists in part because scholars and practitioners assume that traditional leaders are men, and they expect TAs to promote patriarchal practices (Bauer, 2016; Htun and Weldon, 2010). Yet, female traditional leaders are almost as common as female elected representatives in countries such as Malawi and rural Zambia, where matrilineal cultural practices exist. In Malawi, 10 percent of traditional leaders are women, while 13 percent of local and 17 percent of national elected seats are held by females. Some female traditional leaders have also forwarded feminist goals. For instance,

${ }^{3}$ Symbolic representation: "altering gendered ideas about the roles of women and men in politics, raising awareness of what women can achieve as political actors and legitimizing them as political actors, or encouraging women to become involved in politics” (Bauer and Burnet, 2013, 104). 
female senior chief Theresa Kachindamoto of Dedza District in Malawi figured prominently in the world media in April 2016, when she annulled 850 child marriages and suspended all village heads that refused to ban the practice of child marriage. ${ }^{4}$ Among the Chewa people of Malawi, Mozambique, and Zambia, women played a key role in the selection of their paramount Chief, the Kalonga, who rules on behalf of his mother, called Nyangu. In countries like Botswana, while no woman has served as president, a woman has also been paramount chief (Bauer, 2016). ${ }^{5}$ Despite the importance of female traditional leaders in Africa and Asia, their impacts as policy advocates are unexplored.

To address this gap, we employ an original framing experiment embedded in a survey conducted in Malawi in 2016, which allows us to examine the impact of authority type (whether traditional or elected) and authority gender (male versus female) on citizens’ support for human rights reforms linked to women’s rights. Specifically, we randomly assign 1,381 respondents to either a control group or to one of four treatment groups to receive a statement from a male MP, male TA, female MP, or female TA. This allows us to test competing hypotheses drawn from institutional trust and role congruity theories to explain the impact of different messengers on

\footnotetext{
${ }^{4}$ See for instance Huffington Post 'How This Female Chief Broke Up 850 Child Marriages In Malawi’ by Sarah Ruiz-Grossman, 1 April 2016. Retrieved from http:/www.huffingtonpost.com/entry/woman-chief-breaks-up-850-child-marriages-inmalawi_us_56fd51c2e4b0a06d580510da

${ }^{5}$ Other examples of women traditional leaders are the queen mothers in the Akan chieftaincy in Ghana (Mensah et al., 2014, p. 207), and the Ndlovukati, the queen mother in the Kingdom of Swaziland, see Constitution of the Kingdom of Swaziland (Article 7).
} 
citizens’ support for child marriage reforms and to apply both theories in a novel way to traditional governance and policy advocacy.

Our results show that, in the sample as a whole and among female and matrilineal population subgroups, the female TA is as effective as the control. But, the female TA was never significantly more effective than the female MP. Examining average treatment effects, we find that the female MP, male MP, and male TA elicited a backfire effect-a decline in support for the law relative to when no endorsement was presented. The male MP was the most effective messenger among patrilineal citizens, while causing a backfire effect among matrilineal citizens.

Overall, our findings underline important dynamics associated with the promotion of women's rights reform in communities where traditional authorities prevail. Our results suggest that traditional institutions influence citizens' attitudes and that the impact of endorsements depends on authority gender and respondents’ gender and lineage practices. They also suggest some caution when it comes to advocating for sensitive gender reforms. In no case (i.e., in the sample as a whole, or among any sub-group) did an endorsement increase support for the reform relative to the control.

Our results thus emphasize the need for an intersectional theory of policy advocacy that takes into account both authority type and gender, as well as the population group. For subgroups that are familiar with women as leaders, women tend to be trusted advocates for family law reform. This indicates that women leaders are not just tokens, but key gatekeepers for local reforms at least within a policy area where they have stereotyped competences. Our findings, therefore, call for further research that explores how background characteristics of traditional authorities may affect what kind of power they have to change attitudes. 
The article proceeds in five sections. Following this introduction, in section two we introduce the concept of dual governance and explain why a traditional leader's gender is likely to impact policy advocacy effectiveness across policy areas. We proceed by placing child marriage reform and the role of traditional leaders in Malawi in a comparative perspective, focusing on previous work on gender equality in countries with dual governance. In section three, we move to develop our hypotheses about the intersectional impact of authority and gender, and we draw on insights from both institutional trust and gender role congruity theories. Section five presents our results and discussion. It shows that the female traditional leader is, in the sample as a whole, as effective as the control (i.e., average treatment effect), but that various subgroups are affected differently by the endorsements (i.e., heterogeneous treatment effects). A concluding section completes our paper.

\section{DUAL GOVERNANCE AND WOMEN'S RIGHTS: THE CASE OF MALAWI}

Dual governance and traditional leadership is a global phenomenon, found in developing countries in Sub-Saharan Africa, the Middle East, and Asia. In systems of dual governance, ethnic groups are often legally recognized and customary law and other forms of law coexist (Holzinger et al., 2016, p. 469). Across Africa, European colonialization and indirect rule established local intermediaries to govern the capital, leaving TAs intact in the hinterlands (Mamdani, 1996, p. 18). Urban, direct, civil rule spoke the language of civil society and civil rights, while rural tribal authorities enforced tradition. Since independence, governments across Africa have adopted different and evolving strategies toward TAs; some formally incorporated traditional governance institutions into their political systems, while others denied them recognition (Mijiga, 1998; Bank and Southall, 1996). Currently, traditional authorities typically 
play an important role within the area of internal security, land and resource allocation, public health, and matters relating to marriage and inheritance (Holzinger et al., 2016).

TAs have often been seen by scholars and policymakers as antithetical to gender equality, particularly in societies with patrilineal tribes in which the male head benefits from maintaining control over women’s marriage choices. For instance, Charrad’s (2001, p. 233) study of state formation and family law in North Africa shows that strong, patrilineal tribes led states to adopt conservative family laws which allowed tribes to preside over kinship and reproduction, negatively affecting women's rights. Similarly, Htun and Weldon (2010; forthcoming) identify historical state accommodation of cultural, traditional, and religious groups as a cause of resistance against gender equality reforms. These studies show that many religious, traditional, and tribal authorities perceive their continued power as dependent on maintaining control over kinship and reproduction. From here, Hudson et al. argue that the particular kinds of female subordination—child marriage, cousin marriage, prevalence of polygyny, or sanction for honorbased violence against women—“serve as indicators of the degree to which clans are salient to governance in a given society” (2015, p. 540). This literature, which focuses largely on patrilineal tribes, thus points to traditional leaders as a group that would possibly resist gender equality reform rather than promote it.

Villalón’s (2010) study of democratization in the Sahel explains why family law reform has been difficult to achieve in the last few decades, despite governments’ intention to alter discriminatory practices. According to Villalón, elected leaders might not be the strongest champions of change in contexts where they seek to maintain support from religious and traditional leaders. This argument is supported by Kang (2015) who, based on studies from Niger, argues that while women activists are critical drivers of change, state authorities are less 
likely to adopt women's rights policies when conservative religious activists mobilize against them.

In recent years, however, traditional leaders have been included in strategies to challenge discriminatory cultural practices that are considered detrimental to women and children in Malawi and elsewhere. In a comparative study of resistance to child marriage reform in Sudan and Zambia, which have patrilineal as well as matrilineal ethnic groups, Muriaas et al. (2018) found that including traditional leaders in comprehensive campaigns prevented countermobilization. ${ }^{6}$ Through inclusion, traditional leaders gained a sense of ownership over the policy and were trained to increase their understanding of how child marriage contributed to school dropout. Importantly, the strategy did not threaten traditional leaders’ powers_-as law reform only challenged current practices — or their position as administrators of the law.

Inclusion of TAs in programs to promote development and women’s rights is linked to their proximity to the issues and respondents, and the high trust people have in them. Traditional institutions in Malawi play a key role in local communities, and are present across the country. ${ }^{7}$ For most Malawians, traditional leaders combine time-honored as well as cultural functions with serving as government agents to mobilize subjects for development activities in their areas and advancing the government's agenda. Figure 1 shows that the majority of Malawian citizens

\footnotetext{
${ }^{6}$ In these societies, as well as in Malawi, there are two lineage systems, depending on whether citizens trace descent through women (matrilineal) or through men (patrilineal; Kaarhus, 2010). ${ }^{7}$ In Malawi, the role of traditional leaders was legislated as far back as 1912, when the colonial administration passed the District Administration (Native) Ordinance, which created a new hierarchy of “traditional” authority involving principal and village headmen.
} 
consider traditional leaders to be relevant in the democratic political space. Equally, around twothirds of the country's citizens approve of traditional leaders taking part in district council meetings alongside elected councilors. Citizens' high confidence in TAs cannot be directly linked to accountability, at least in the form of electoral accountability; TAs are not elected and are not easily removed, but the president can reduce chiefs’ privileges and status.

Figure 1. Perceived relevance of traditional leaders and acceptance of their participation in district council meetings. Source: Department of Political and Administrative Studies, University of Malawi, and Centre for Development and the Environment, University of Oslo, 2016. Question wording: "Do you approve or disapprove of the current system of having TAs sit as members of the District Council?" "In your opinion, how relevant are traditional leaders in modern day Malawi. Would you say they are not relevant at all, not relevant, relevant or very relevant?”

Efforts to include traditional leaders as partners are based on studies showing a high degree of popular trust in traditional leadership. Survey results from the Afrobarometer reinforce the high public regard that TAs in Malawi enjoy as compared to elected officials. Malawians are more likely to approve of the performance of TAs than MPs. Figure 2 illustrates that TAs are more trusted than the MPs. 
Figure 2. Trust and performance approval for traditional and elected leaders in Malawi (Afrobarometer, 2014). Source: Afrobarometer R6 2014.Question wording: "How much do you trust each of the following, or haven't you heard enough about them to say?" "Parliament," "Traditional leaders." "Do you approve or disapprove of the way that the following people have performed their jobs over the past twelve months, or haven't you heard enough about them to say?" "Your MP" and "Your traditional leader."

In addition to being a country where traditional leaders are held in high regard, trusted, and seen as more accessible, Malawi is a useful case because it has undergone several attempts to implement reforms that address long-standing cultural traditions considered discriminatory and obstructive to effective development. A recent legal reform in this respect is the Marriage, Divorce, and Family Relations Act (The Marriage Act) of 2015, which banned child marriage. Child marriage is commonly defined as a formal marriage or informal union entered into before the age of 18. The importance of this reform is underscored by the fact that Malawi has one of the highest rates of child marriage in the world: 50\% of girls marry before age 18 (UNFPA, 2012). The country is ranked $9^{\text {th }}$ internationally in terms of child marriage prevalence (UNICEF, 2015), which is common across all three regions of the country, but highest in the central region (57\%). 
Although other studies that seek to examine public support for law reforms on issues ranging from female genital mutilation, criminalizing spousal abuse, and ending child marriage have established some levels of social desirability bias among survey respondents (see e.g. Cloward, 2014), public support for the law banning child marriage remains important in a number of ways. Public support makes the enforcement of the law less costly on the state, as members of the public and local leaders can be relied upon to police the application of the law. Additionally, reforms that seek to induce behavioral change, as is the case of the Marriage Act, are more likely to succeed if they are accepted by the wider public (Bilz and Nadler, 2014, p. 246). This is particularly the case as customary norms and practices are identified as factors contributing to upholding the practice in Malawi (WLSA and NGOGCN, 2009; Panos, 2015). ${ }^{8}$

To curb the practice of child marriage, international development agents and the Malawi government emphasized the importance of including traditional leaders in the campaign (Kachali, 2013; Chimjeka, 2016). This is unsurprising, since most child marriages are conducted under customary law and presided over by village headmen, who are widely considered in Malawian society to be custodians of culture (Cammack et al., 2009). Traditional leaders across the country have been urged by the government to develop action plans against child marriage and have attended workshops where they have been acquainted with different aspects of the law. While senior chief Theresa Kachindamoto is the most well-known activist of the campaign,

\footnotetext{
${ }^{8}$ In Malawi the key argument used to gather support for the child marriage reform was that early marriage causes girls to drop out of school. Another important argument was that a consequence of early pregnancies is worsening of women's health due to for instance the preponderance of fistulas, and how this again affects women's participation in the economy negatively.
} 
several male traditional leaders have also endorsed it (Kachali, 2013). It is, however, likely that we will find clear differences between Malawians with different cultural backgrounds, as well as variation in the traditional norms of the two lineages systems, matrilineal and patrilineal, which have different practices with regard to women’s role in political leadership (Posner, 2004, p. 533).

\section{WHO MAKES A GOOD POLICY ADVOCATE? MESSENGER INSTITUTION AND GENDER}

We draw on gender role congruity and institutional trust to anticipate the effects of male and female traditional and state authorities on citizens' views of child marriage. Combining these two theoretical models enables us to understand how messenger institution and gender intersectionally shape popular views across different population subgroups.

\section{The Role of Messenger Institution: Trust}

Much of the existing literature on endorsement experiments is drawn from social psychology and communications theory and argues that the impact of endorsements depends on the extent to which receivers trust the messenger. Following Arceneaux and Kolodny (2009), authority cues could compensate for respondents’ lack of awareness about politics. Receivers are likely to be swayed by messages from those they trust without analyzing the content of the endorsement. This occurs because receivers use simple heuristics, such as whether or not they like or trust the source, when engaging with endorsements (Carmines and Kuklinski, 1990; Mondak, 1993). Consistently with this theory, Masoud et al. (2016) find that respondents exposed to an argument in favor of women's political empowerment grounded in a religious 
rather than a nonreligious argument are more likely to express support for female political leaders, due to their trust in religious institutions.

Applied to our endorsement experiment comparing messengers from two institutions, an institutional trust theory leads us to expect that TAs are more effective messengers than state authorities, due to their proximity to the people and the high trust placed in them by the public. It follows that male and female TAs will be more effective than male and female MPs (H1). ${ }^{9}$

\section{The Role of Messenger Gender: Gendered Authority and Policy Congruence}

Yet, existing literature examining the impact of traditional authorities (Bush and Jamal, 2015) or institutions (Masoud et al., 2016) does not theorize about how the impact of these endorsers depends intersectionally on their gender. To theorize about this, we draw on gender role congruity theory and related work from women and politics research. Gender role congruity theory was originally developed by Eagly and Karau (2002) to explain women's underrepresentation in business leadership and has subsequently been applied to political leadership (King and Matland, 2002; Benstead et al., 2015). Gender role congruity theory stipulates that prejudice against female leaders arises from the incongruity between traits associated with the female gender roles (e.g., that women are nurturing) and leadership roles (e.g., decisiveness), which are based on leaders of the past, who are often men. Stemming from

\footnotetext{
${ }^{9} \mathrm{~A}$ related literature on the influence of cue sources suggests that political information has a greater impact not only when the recipient trusts the messenger, but also when the message goes against the sender's interests and thus seems more credible (Dragojlovic, 2015; Weber, Dunaway, and Johnson, 2012). This would suggest that male TAs and MPs will be more effective than female TAs and MPs.
} 
descriptive norms, women as potential occupants of leadership roles are evaluated less favorably than men because leadership ability is more stereotypical of men than women. Originating from injunctive norms, women’s leadership behavior is evaluated less positively because such behavior is perceived as less desirable in women than men (Eagly and Karau, 2002; Eagly and Diekman, 2006).

One possible implication of gender role congruity theory is that, on the whole, women will be seen as less authoritative than men and thus be less successful policy endorsers. Yet, to the extent that policy domain is considered consistent with behavior that is perceived as appropriate for women (e.g., to be concerned with family and gender issues), their leadership may be more welcome. Related work in women and politics posits that political leaders will be stereotyped as having different policy competencies, related to traditional gender roles, and this leads to slightly different expectations in a context in which the policy—child marriage—is closely linked to the stereotyped traits and competencies of women. While men are often associated with having the traits needed for effective leadership, male and female leaders are stereotyped as more competent in policy domains consistent with gender roles (Huddy and Therkildsen, 1993; Rosenwasser and Seale, 1988; Lawless, 2004). ${ }^{10}$ Women are seen as competent in policy areas such as children, marriage, family, and education, while men are stereotyped as competent in areas such as economy, land, and security. Since the policy domain examined in this study relates to perceived female competencies, a competing expectation to that of under-evaluation and male authority is that female TAs and MPs will be seen as more

\footnotetext{
${ }^{10}$ Consistently with this theory, women often play a central role in advocating for policies that are consistent with liberal gender laws (Bauer 2012; Wang, 2013).
} 
competent messengers of anti-child marriage (i.e., family-related) messages and will sway public opinion more in the intended direction than will male TAs and MPs (H2).

It may also be the case that institutional trust and gender role congruity theory work in tandem, producing intersectional effects. H3 posits that the female TA, since she benefits from both high trust (H1) as well as perceived policy competence (H3) will be more effective than other endorsers.

Average treatment effects:

H1: Overall, TAs will be more effective endorsers of anti-child marriage messages than MPs. (Institutional trust hypothesis)

H2: Overall, female authorities will be more effective endorsers of anti-child marriage messages than male authorities. (Gendered policy competence hypothesis)

H3: Overall, Female TAs will be more effective than other endorsers. (Intersectional hypothesis)

\section{Heterogeneous Effects}

Institutional trust and gender role congruity theories also lead us to expect stronger impacts among citizens who are more likely to trust and hold more gender role congruent attitudes toward female leaders—namely, female and matrilineal citizens. Gender congruent attitudes are those that are more accepting of women as equally good political leaders, due to overlapping gender and leader roles (Eagly and Karau, 2002). ${ }^{11}$ Males have the role of family

\footnotetext{
${ }^{11}$ Role incongruity prejudice is found to be moderated by a number of conditions, including the definition of leader roles, the weight given to the leader roles relative to the female gender role,
} 
head in both family structures, but in matrilineal communities women are surrounded by their natal extended families rather than those of their husbands and, therefore, may be able to assert more authority (Phiri, 1983). Although a shift towards increasing male control has been noted within matrilineal lineage systems, the authority of women in these systems has also proven very resilient (Peters, 1997). This implies that female and matrilineal citizens not only hold more role congruent views, but also that they will have higher trust in female leaders than will male and patrilineal citizens.

\section{Heterogeneous treatment effects:}

H4: Female messengers will increase support more among female than male respondents. H5: Female messengers will increase support more among matrilineal than patrilineal citizens respondents.

Thus far, we have considered the relative impact of the four authority types relative to one another. Now, we consider how endorsements might impact attitudes relative to the control conditions - that is, no endorsement. Literature from political psychology shows that people process information in a way that is consistent with their preexisting beliefs and often engage in motivated reasoning (Kunda, 1990; Molden and Higgins, 2005; Goren et al., 2009). Scholars identify two mechanisms: biased assimilation — effects in the direction of the information—and backfire effects_-impacts in the opposite direction of the statements. Lord et al. (1979) demonstrated biased assimilation by showing how scientific studies confirming participants’

gender (men often show stronger prejudice), and time-e.g., change of attitudes about gender roles over time and change in the definition of leader roles (Eagly and Karau, 2002). 
attitudes were interpreted more positively than studies disconfirming their attitudes. Multiple laboratory studies later corroborated this bias (Edwards and Smith, 1996; Miller et al., 1993; Zuwerink and Devine, 1996), as have field studies (e.g., Ahluwalia, 2000; Munro et al., 2002).

However, other evidence across different experimental contexts shows that distrust of the messenger can also lead to strong, often contradictory, responses. Instead of discounting information from a source that is mistrusted, the recipient comes to hold even stronger views after encountering the message. Referred to as a backfire effect, this occurs because recipients spend more time considering and counter-arguing the information, arriving at more strongly held views than they had before (Nyhan and Reifler, 2010). Ditto and Lopez (1992) first identified a backfire effect when participants in experiments required more information to reach a preference-inconsistent conclusion than a preference-consistent conclusion and processed information more critically. In another study of citizen misperceptions, Nyhan and Reifler (2010) conducted experiments in which they document several instances of backfire effects when corrections increase misconceptions. In a study of support for women's representation in Jordan, endorsements by authorities, like religious leaders and American actors, depressed support significantly more among regime critical women compared to loyalists (Bush and Jamal, 2015: p. 35).

Accordingly, we anticipate that endorsements could have a negative impact-referred to as a backfire effect — relative to the control and this effect could be particularly pronounced among those who have less trust in female endorsers - that is, male and patrilineal citizens. Backfire effects (relative to the control) are also possible in the sample as a whole, particularly if they are sufficiently strong among a large segment of the population. Thus, we expect that effects can be positive among those who trust the messenger (relative to the control) - evidence 
for biased assimilation — or negative among those who do not trust the messenger (relative to the control)—evidence for backfire effects.

\section{$\underline{\text { Heterogeneous treatment effects: }}$}

H6: (i) Female messengers will increase support more among female and matrilineal respondents relative to the control. (ii) Male messengers will increase support more among male and patrilineal respondents relative to the control. (Biased assimilation)

H7: (i) Female messengers will decrease support more among male and patrilineal respondents relative to the control. (ii) Male messengers will decrease support more among female and matrilineal respondents relative to the control. (Backfire effect)

\section{DATA AND METHODS}

To assess the factors that shape greater support for laws setting the age of marriage at 18 years of age and the impact of different messengers on support for these laws, we draw on a survey experiment embedded within the Local Government Performance Index (LGPI), conducted in Malawi in 2016. ${ }^{12}$ Regular public opinion surveys and other kinds of observational data may not be able to detect prejudice against female authorities, either because gender prejudices are subconscious or because the answers are tainted by socially desirable responses

${ }^{12}$ Lust, E., Harris, A., Kao, K. Landry, P.F., Dulani, B., Zgambo, A., Chiweza, A., Kayuni, H., Muriaas, R.L., Rakner, L., Wang, V., Benstead, L., Hartmann, F., and Nickel, S. (2016) “The Local Governance Performance Index (LGPI) Malawi Dataset.” Program on Governance and Local Development, University of Gothenburg. Replication files for this article are available on the Comparative Political Studies website. 
(Dolan and Sanbonmatsu, 2011, p. 289). A probability-based survey experiment allows us to implicitly test the power of gender cues relative to the power of authority cues on citizens' attitudes, while reducing the effects of social desirability and conformity bias (Benstead, 2014).

The survey used probabilistic sampling to select 17 TA areas in rural Malawi and an additional five local government wards in urban centers. Post-stratification weights were added to correct imbalances created by differential response rates across population sub-groups, especially an under-representation of men, many of whom were working in neighboring villages, towns, or outside the country. The response rate was 94.5\% (AAPOR Response Rate 1).

While 7,500 Malawians participated in the survey, 1,381 randomly selected respondents received the experimental prompts. Tests showed that the random assignment of participants into the sample was effective and there were no differences in response rates across the frames. However, the condition was significantly related to cultural customs (see Appendix 1). Therefore, we include several control variables in the ordered logistic regressions.

\section{Survey Design}

To understand the role of different authorities in increasing opposition to child marriage, we asked respondents to rate on a four-point scale the extent to which they agree that the minimum age of marriage should be raised to 18. A control group received no frame; respondents from this group were simply asked the extent to which they would support the law to increase the marriage age to 18 . Four treatment groups received the endorsement of a female MP, female TA, male MP, or male TA before being asked whether they would support the law (Table 1). 


\section{Table 1. Experimental design}

\section{Control:}

The parliament has passed a new law that sets the minimum age of marriage at 18. What do you think of the law? Do you support it strongly, support it, not support it, or not support it strongly? $(\mathrm{N}=286)$

\section{Female MP:}

A female MP is supporting the new law that sets the minimum age of marriage at 18 . What do you think of the law? Do you support it strongly, support it, not support it, or not support it strongly? $(\mathrm{N}=265)$

\section{Female TA:}

A female TA is supporting the new law that sets the minimum age of marriage at 18. What do you think of the law? Do you support it strongly, support it, not support it, or not? $(\mathrm{N}=272)$

\section{Male MP:}

A male MP is supporting the new law that sets the minimum age of marriage at 18 . What do you think of the law? Do you support it strongly, support it, not support it, or not support it strongly? $(\mathrm{N}=266)$

\section{Male TA:}

A male TA is supporting the new law that sets the minimum age of marriage at 18. What do you think of the law? Do you support it strongly, support it, not support it, or not support it strongly? $(\mathrm{N}=283)$

The conditions are realistic in Malawi. In 2014, 17 percent of candidates winning a seat in the national parliament (193 members) were women, which means that Malawi scores beneath the regional average of 23.5\% (Inter-Parliamentary Union, 2017). Out of the total of 257 TAs for example, only 25 (10 percent) are women. Women chiefs are most common in the densely populated southern region where matrilineal lineage systems dominate and particularly in Mulanje, Phalombe, Thyolo, and Zomba. This is just slightly lower than the 13 percent and 17 
percent of women representation at local government and parliamentary levels respectively (Dulani and Dionne, 2014).

We carefully considered different ways of formulating the control and the treatment conditions in order to make them as similar as possible. Some might consider the control to be a stronger statement because it mentions that the new law was passed by parliament, while the treatments stated that the new law was supported by different actors. However, we see no reason that the new law being passed as opposed to being supported would connote a stronger treatment. This is because we expect that respondents would have interpreted this question through the lens of the Marriage, Divorce and Family Relations Law of 2015. At the time of the survey in 2016 there was still continuing public debate over the provisions of the new law and also ongoing initiatives by government, legislators, and civil-society organizations to sensitize the public to the new law. The term law, as opposed to bill, in the Malawian setting denotes a rule or regulation that has been passed by parliament (and assented to by the president), and is legally enforceable.

\section{Descriptive Statistics}

Overall—i.e., in all conditions combined (Figure 3)—-there is high support for a law banning child marriage: 76\% answered that they strongly support, 10\% support, and 14\% do not support. Support for the law is not significantly higher among women, but it is higher in matrilineal areas $(\mathrm{p}<.05)$ and among those who support gender equality a priori $(\mathrm{p}<.01)$. 
Figure 3. Support for banning child marriage (all conditions). Data weighted.

As shown in Figure 4, Malawians have higher trust in their TA than their MP: 53\% of respondents trust their TA very much, compared to 28\% trusting their MP very much. As noted, these findings are consistent with other studies presented in figure 1 and 2 (earlier in the article). These questions do not distinguish between trust in leaders of different genders, nor do they distinguish between different policy competencies, which we believe will differ across advocates, based on their gender and possibly their institution. 
Figure 4. Trust in TAs and MPs in Malawi (\%). Data weighted. For question wording: "For each of the following, please tell me whether you trust them very much, trust them somewhat, distrust them somewhat, or distrust them very much to work for your interests? Your Traditional Authority. Your Member of Parliament.”

\section{Measurement of Independent Variables for Testing Heterogeneous Treatment Effects}

We also measured several independent variables pretreatment—respondent sex and lineage system—which allow us to test our core heterogeneous hypotheses. We measure cultural practices as the response to the question: “In your family, is lobola [bride price/dowry] paid when people get married?” Yes (=0/Patrilineal). No (=1/Matrilineal). The sample is made up of $35 \%$ male and $65 \%$ female citizens. Among the respondents in the experiment, $51 \%$ follow a matrilineal system, while $49 \%$ follow patrilineal customs. ${ }^{13}$ We expect females and those from

${ }^{13}$ In the survey, respondents from the Northern region were disproportionately sampled to increase the patrilineal respondents. This means that the 51-49 split is a function of the sample clustering and does not imply that there is an almost evenly split between patrilineal and matrilineal customs in Malawi. 
matrilineal areas to have more gender role congruent views and higher trust in female leaders than males and those from patrilineal areas.

\section{RESULTS AND DISCUSSION}

To test the impact of messenger institution and gender, we first estimate average treatment effects. Then we examine conditional treatment effects across independent variables theoretically related to gender role congruity and institutional trust theory. Because the outcome variable is measured on a Likert scale, we use ordered logistic regression rather than means comparisons, using a methodology developed by Long and Freese (2014). Inclusion of additional demographic control variables for which heterogeneous treatment effects, unless theoretically justified, is unnecessary in a randomized treatment assignment and can bias estimation of the average treatment effects (Mutz, 2011). ${ }^{14}$

Randomization was effective across primary sampling units. However, because the treatment was related to lineage system, we include several control variables in the models. These include: respondent and interviewer gender (Benstead, 2014), whether the respondent follows matrilineal or patrilineal customs, rural residence, age, income quartile, and education level, as well as post-stratification weights. (See Appendix 2 Tables A2.1 and A2.2 for full regression results). We also conducted robustness checks by running the models with only

\footnotetext{
${ }^{14}$ We estimate the models using Stata 14 updated on May 1, 2017 using current update level March 16, 2017. Replications using update levels prior or subsequent to these dates may obtain slight differences in p values.
} 
respondent gender and cultural customs included and found that our results were robust to this alternative specification.

\section{Average Treatment Effects}

Overall, as shown in Figure 5 and Table 2, support for the reform was higher when endorsed by one of the female messengers than by either of the male messengers: 75\% and 78\% strongly supported the reform when advocated by a female MP or TA, respectively, while only $74 \%$ and $72 \%$ strongly supported the reform when advocated by a male MP or TA, respectively. The female TA was the most effective overall, while the male TA was the least effective. However, none of the treatments were significantly different from one another.

Yet, all of the endorsements except for the female TA are significantly less effective than the control at the $\mathrm{p}<.10$. This suggests that the only treatment that did not lower support for the reform is the female TA. In the sample as a whole, all of the other treatments produced backfire effects. In the control condition, $80 \%$ are very likely to support the reform, compared to $78 \%$ for the female TA, a non-significant difference. Yet, 75\% strongly support the reform when it is endorsed by the female MP, significantly fewer than in the control condition $(\mathrm{p}<.05)$. The probability is $74 \%$ for the male MP ( $\mathrm{p}<.10$ relative to the control) and $72 \%$ for the male TA ( $\mathrm{p}<.10$ relative to the control), the least effective messenger. 
Figure 5. Average treatment effects

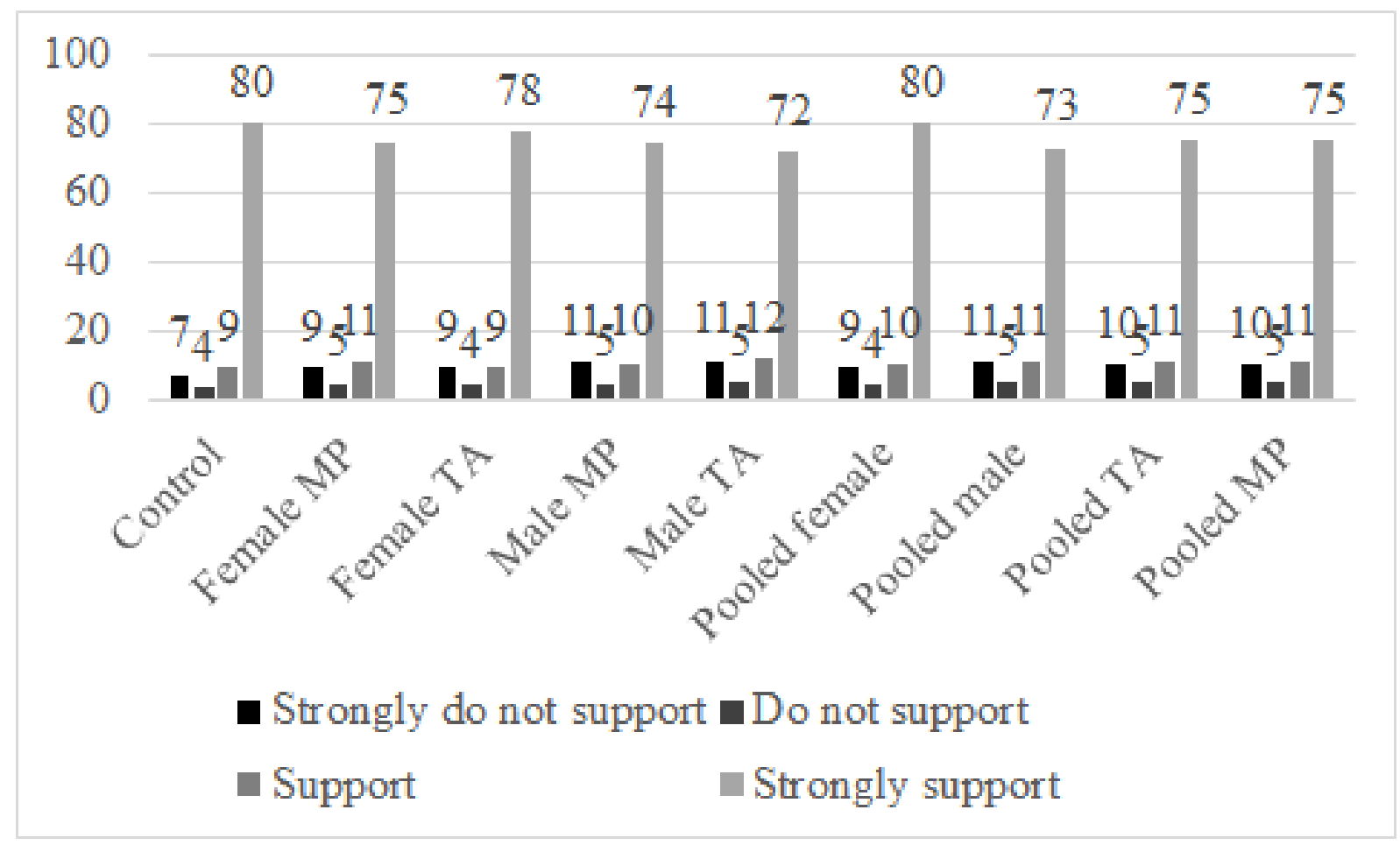

Figure 5 shows predicted probabilities for supporting or opposing the law. Model includes controls for respondent gender, interviewer gender, cultural customs, attitudes about gender equality, rural residence, education, income (asset index), and age. Post-stratification weights included. 
Table 2. Significance levels for pairwise comparisons (average treatment effects)

\begin{tabular}{|c|c|c|c|c|}
\hline & Strongly do not support & Do not support & Support & Strongly support \\
\hline \multicolumn{5}{|l|}{ Comparisons of treatments with control } \\
\hline Female MP vs. control (2 vs. 1) & $.049 *$ & $0.063 \dagger$ & $0.052 \dagger$ & $0.037^{*}$ \\
\hline Female TA vs. control (3 vs.1) & 0.301 & 0.506 & 0.881 & 0.452 \\
\hline Male MP vs. control (4 vs. 1 ) & $.062 \dagger$ & .106 & 0.227 & $.073 \dagger$ \\
\hline Male TA vs. control (5 vs.1) & $.088 \dagger$ & $.076 \dagger$ & $.083 \dagger$ & $.071 \dagger$ \\
\hline \multicolumn{5}{|c|}{ Comparisons of institutions (State vs. traditional) } \\
\hline Female TA vs. MP (3 vs. 2) & 0.862 & 0.365 & 0.124 & 0.449 \\
\hline Male TA vs. MP (5 vs. 4 ) & 0.769 & 0.574 & 0.335 & 0.566 \\
\hline \multicolumn{5}{|l|}{ Comparisons of gender (Female vs. male) } \\
\hline Male vs. female MP (4 vs. 2) & 0.473 & 0.872 & 0.457 & 0.845 \\
\hline Male vs. female TA (5 vs. 3) & 0.370 & 0.151 & $.078 \dagger$ & 0.181 \\
\hline \multicolumn{5}{|l|}{ Other comparisons } \\
\hline Male TA vs. female MP (5 vs. 2) & 0.396 & 0.501 & 0.684 & 0.482 \\
\hline Male MP vs. female TA (4 vs. 3) & 0.536 & 0.349 & 0.333 & 0.405 \\
\hline \multicolumn{5}{|l|}{ Pooled comparisons (Gender) } \\
\hline Female vs. control (2 vs. 1 ) & 0.128 & 0.107 & 0.146 & 0.100 \\
\hline Male vs. control (3 vs. 1) & $0.044 *$ & $0.047 *$ & $0.041^{*}$ & $0.034 *$ \\
\hline Male vs. female (3 vs. 2) & 0.324 & 0.245 & 0.212 & 0.249 \\
\hline \multicolumn{5}{|l|}{ Pooled comparisons (Institution) } \\
\hline TA vs. control (2 vs. 1 ) & 0.210 & 0.130 & 0.136 & 0.148 \\
\hline MP vs. control (3 vs. 1) & $0.060 \dagger$ & $0.076 \dagger$ & $0.058 \dagger$ & $0.046 *$ \\
\hline MP vs. TA (3 vs. 2) & 0.883 & 0.864 & 0.923 & 0.888 \\
\hline
\end{tabular}

${ }^{* * *} \mathrm{p}<.001,{ }^{* *} \mathrm{p}<.01,{ }^{*} \mathrm{p}<.05, \dagger \mathrm{p}<.10$.

We also examined pooled comparisons (Table 2) and found that, in the sample as a whole, the female messengers (i.e., both female MP and female TA) do not differ from the 
control, but male messengers (i.e., both male MP and female TA) produce a backfire effect relative to the control (p.05). So too, the parliamentarians lead to a backfire effect relative to the control $(\mathrm{p}<.05)$.

These pooled comparisons strengthen our initial findings. None of the endorsers, overall, are more effective in fostering support for the reform when compared to one another, the female TA does not cause a backfire effect, relative to the control. This suggests that TAs may be effective endorsers, but that their effect depends on their gender-an intersectional effect that suggests support for H3. At the same time, the average treatment effects indicate some troubling evidence about potential backfire effects that need to be further investigated through an examination of heterogeneous effects.

\section{Heterogeneous Treatment Effects}

Next, we examine effects across respondent gender and cultural customs, which relate to the likelihood of holding gender congruity views and trusting the authorities. We expect female messengers to be more effective among female respondents than male (H4) and among matrilineal than patrilineal (H5) respondents. This, we argue, is because female and matrilineal citizens are likely to have more gender role congruent views and higher trust in female leaders.

Indeed, we find support for both hypotheses (H4 and H5). Among women, female messengers are more effective than male messengers, as predicted by H4 (Figure 6 and Table 3): 85\% strongly support the reform when endorsed by a female TA, while $76 \%$ support for reform for a female MP. This compares to $68 \%$ for a male TA and $75 \%$ for a male MP. The difference in the support for the female TA and the male TA is statistically significant $(\mathrm{p}<.05)$. This suggests that for female respondents, TAs are most effective, but only in compared to the male TA $(\mathrm{p}<.05)$, not the male MP, which is consistent with an intersectional theory (H3) among 
female citizens. Among male respondents, (see Appendix 2 Figure A2.1 and Table A2.3), there are no significant differences across the messengers. This may be due in part to the smaller size of male sample size.

Figure 6. Predicted probability, women

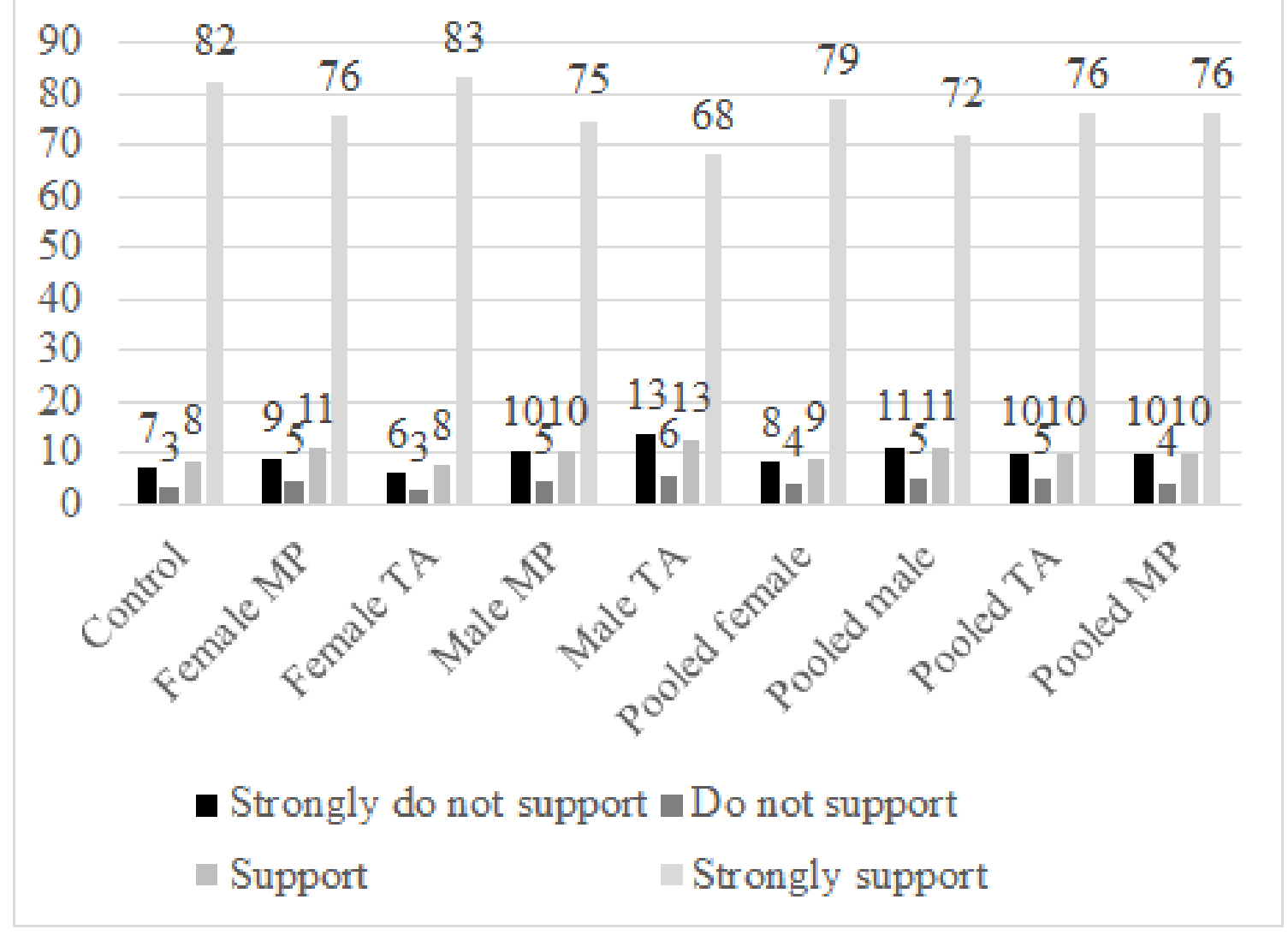

Figure 6 shows predicted probability of supporting the law among women. 
Table 3. Significance levels for pairwise comparisons (women)

\begin{tabular}{|c|c|c|c|c|}
\hline & Strongly do not support & Do not support & Support & Strongly support \\
\hline \multicolumn{5}{|c|}{ Comparisons of treatments with control } \\
\hline Female MP vs. control (2 vs. 1) & 0.333 & 0.321 & 0.353 & 0.332 \\
\hline Female TA vs. control (3 vs. 1) & 0.998 & 0.935 & 0.862 & 0.937 \\
\hline Male MP vs. control (4 vs. 1 ) & 0.134 & 0.239 & 0.427 & 0.215 \\
\hline Male TA vs. control (5 vs. 1 ) & $.094 \dagger$ & .105 & 0.169 & .105 \\
\hline \multicolumn{5}{|c|}{ Comparisons of institutions (State vs. traditional) } \\
\hline Female TA vs. MP (3 vs. 2) & 0.325 & 0.249 & 0.154 & 0.234 \\
\hline Male TA vs. MP (5 vs. 4) & 0.443 & 0.298 & 0.224 & 0.319 \\
\hline \multicolumn{5}{|c|}{ Comparisons of gender (Female vs. male) } \\
\hline Male vs. female MP (4 vs. 2) & 0.546 & 0.839 & 0.593 & 0.816 \\
\hline Male vs. female TA (5 vs. 3) & $.045^{*}$ & $.032 *$ & $.012 *$ & $.021^{*}$ \\
\hline \multicolumn{5}{|l|}{ Other comparisons } \\
\hline Male TA vs. female MP (5 vs. 2) & 0.200 & 0.230 & 0.300 & 0.215 \\
\hline Male MP vs. female TA (4 vs. 3) & 0.257 & 0.291 & 0.283 & 0.258 \\
\hline \multicolumn{5}{|l|}{ Pooled comparisons (Gender) } \\
\hline Female vs. control (2 vs. 1) & 0.128 & 0.107 & 0.146 & $0.100 \dagger$ \\
\hline Male vs. control (3 vs. 1) & $0.044^{*}$ & $0.047^{*}$ & $0.041^{*}$ & $0.034 *$ \\
\hline Male vs. female (3 vs. 2) & 0.324 & 0.245 & 0.212 & 0.249 \\
\hline \multicolumn{5}{|l|}{ Pooled comparisons (Institution) } \\
\hline TA vs. control (2 vs. 1 ) & 0.162 & 0.166 & 0.112 & 0.131 \\
\hline MP vs. control (3 vs. 1) & $0.055 \dagger$ & 0.119 & $0.052 \dagger$ & $0.053 \dagger$ \\
\hline MP vs. TA (3 vs. 2) & 0.996 & 0.980 & 0.978 & 0.998 \\
\hline
\end{tabular}

$* * * \mathrm{p}<.001,{ }^{* *} \mathrm{p}<.01,{ }^{*} \mathrm{p}<.05, \dagger \mathrm{p}<.10$.

Analysis of pooled comparisons (Table 3) shows that, among female respondents, there is a backfire effect for male messengers relative to the control $(p<.05)$ and for MPs relative to the control ( $\mathrm{p}<.10)$. Among male respondents (not shown in the table), there is a backfire effect for 
MPs relative to the control $(\mathrm{p}<.10)$. These findings strengthen our initial result that female TAs are as effective as the control, but that an intersectional theory of policy advocacy is needed.

Female messengers are also more effective for matrilineal than patrilineal citizens, consistent with H5 (Figure 7 and Table 4). Among matrilineal citizens, 83\% strongly support the reform when endorsed by a female TA, while $82 \%$ support for reform for a female MP. This compares to $80 \%$ for a male TA and $73 \%$ for a male MP. The difference in the support for the female MP and the male MP is statistically significant $(\mathrm{p}<.05)$. This suggests that for one institution—parliament—female are more effective endorsers than male messengers $(\mathrm{p}<.05)$.

\section{Figure 7. Predicted probability, Matrilineal customs}

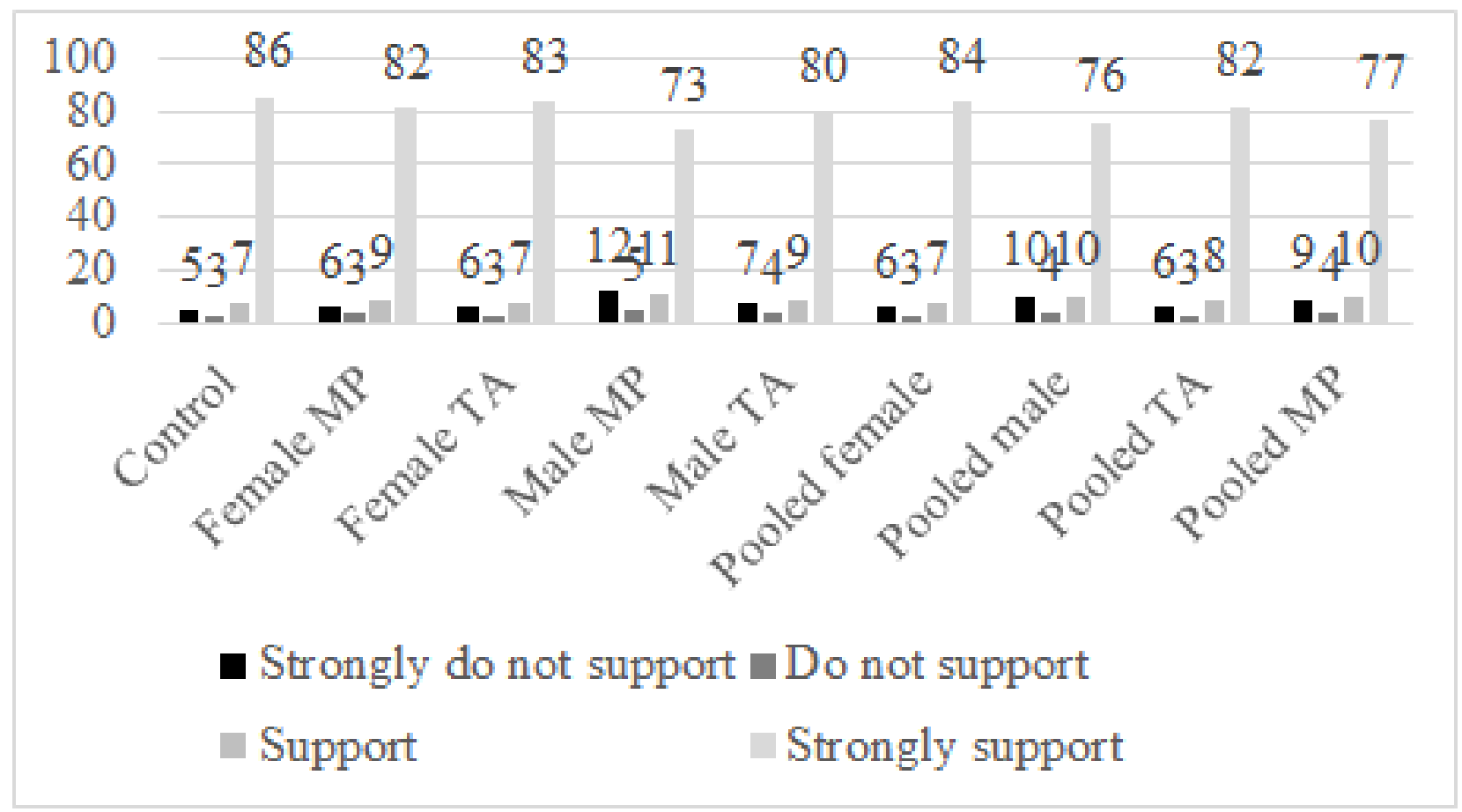

Figure 7 shows predicted probability of supporting the law among citizens with matrilineal customs. 
Table 4. Significance levels for pairwise comparisons (matrilineal)

\begin{tabular}{|c|c|c|c|c|}
\hline & Strongly do not support & Do not support & Support & Strongly support \\
\hline \multicolumn{5}{|c|}{ Comparisons of treatments with control } \\
\hline Female MP vs. control (2 vs. 1) & .392 & 0.335 & 0.330 & 0.349 \\
\hline Female TA vs. control (3 vs. 1) & .363 & 0.523 & 0.769 & 0.506 \\
\hline Male MP vs. control (4 vs. 1 ) & $.004 * *$ & $.004^{* *}$ & $.002 * *$ & $.001^{* * *}$ \\
\hline Male TA vs. control (5 vs. 1 ) & .305 & 0.288 & 0.296 & 0.291 \\
\hline \multicolumn{5}{|c|}{ Comparisons of institutions (State vs. traditional) } \\
\hline Female TA vs. MP (3 vs. 2) & .946 & 0.649 & 0.404 & 0.676 \\
\hline Male TA vs. MP (5 vs. 4) & .165 & 0.214 & 0.396 & 0.197 \\
\hline \multicolumn{5}{|c|}{ Comparisons of gender (Female vs. male) } \\
\hline Male vs. female MP (4 vs. 2) & $.025 *$ & $.085 \dagger$ & 0.183 & $.037 *$ \\
\hline Male vs. female TA (5 vs. 3) & .703 & 0.555 & 0.443 & 0.573 \\
\hline \multicolumn{5}{|l|}{ Other comparisons } \\
\hline Male TA vs. female MP (5 vs. 2) & .739 & 0.799 & 0.870 & 0.795 \\
\hline Male MP vs. female TA (4 vs. 3) & $.048 *$ & $.012 *$ & $.013 *$ & $.016^{*}$ \\
\hline \multicolumn{5}{|l|}{ Pooled comparisons (Gender) } \\
\hline Female vs. control (2 vs. 1 ) & 0.515 & 0.481 & 0.470 & 0.482 \\
\hline Male vs. control (3 vs. 1 ) & $0.013 *$ & $0.013^{*}$ & $0.009 * *$ & $0.007 * *$ \\
\hline Male vs. female (3 vs. 2) & $0.037^{*}$ & $0.044 *$ & $0.030^{*}$ & $0.029 *$ \\
\hline \multicolumn{5}{|l|}{ Pooled comparisons (Institution) } \\
\hline TA vs. control (2 vs. 1 ) & 0.308 & 0.291 & 0.260 & 0.276 \\
\hline MP vs. control (3 vs. 1) & $0.026^{*}$ & $0.011^{*}$ & $0.008^{* *}$ & $0.008^{* *}$ \\
\hline MP vs. TA (3 vs. 2 ) & 0.221 & 0.180 & 0.199 & 0.192 \\
\hline
\end{tabular}

$* * * \mathrm{p}<.001, * * \mathrm{p}<.01,{ }^{*} \mathrm{p}<.05, \dagger \mathrm{p}<.10$.

The results of the pooled comparison among matrilineal citizens show that male messengers cause a backfire effect relative to the control $(\mathrm{p}<.01)$ and are less effective than 
female messengers $(\mathrm{p}<.05)$. Moreover, MPs cause a backfire effect relative to the control $(\mathrm{p}<.01)$. This only strengthens our initial finding about the effectiveness of female messengers among matrilineal citizens, but the need to engage an intersectional approach that takes messenger institution and gender into account (H3).

Among patrilineal citizens, however, this is not the case, as hypothesized (H5; Figure 8 and Table 5). Among this group, the most effective endorser is the male MP, for whom $76 \%$ strongly support the reform. Yet, the female TA still garners the second highest support level— 72\% - higher than the female MP (67\%) and the male TA (63\%). The difference in the support for the male MP and TA is statistically significant $(\mathrm{p}<.05)$. This suggests that for one institution — the TA—males are more effective endorsers.

\section{Figure 8. Predicted probability, Patrilineal customs}

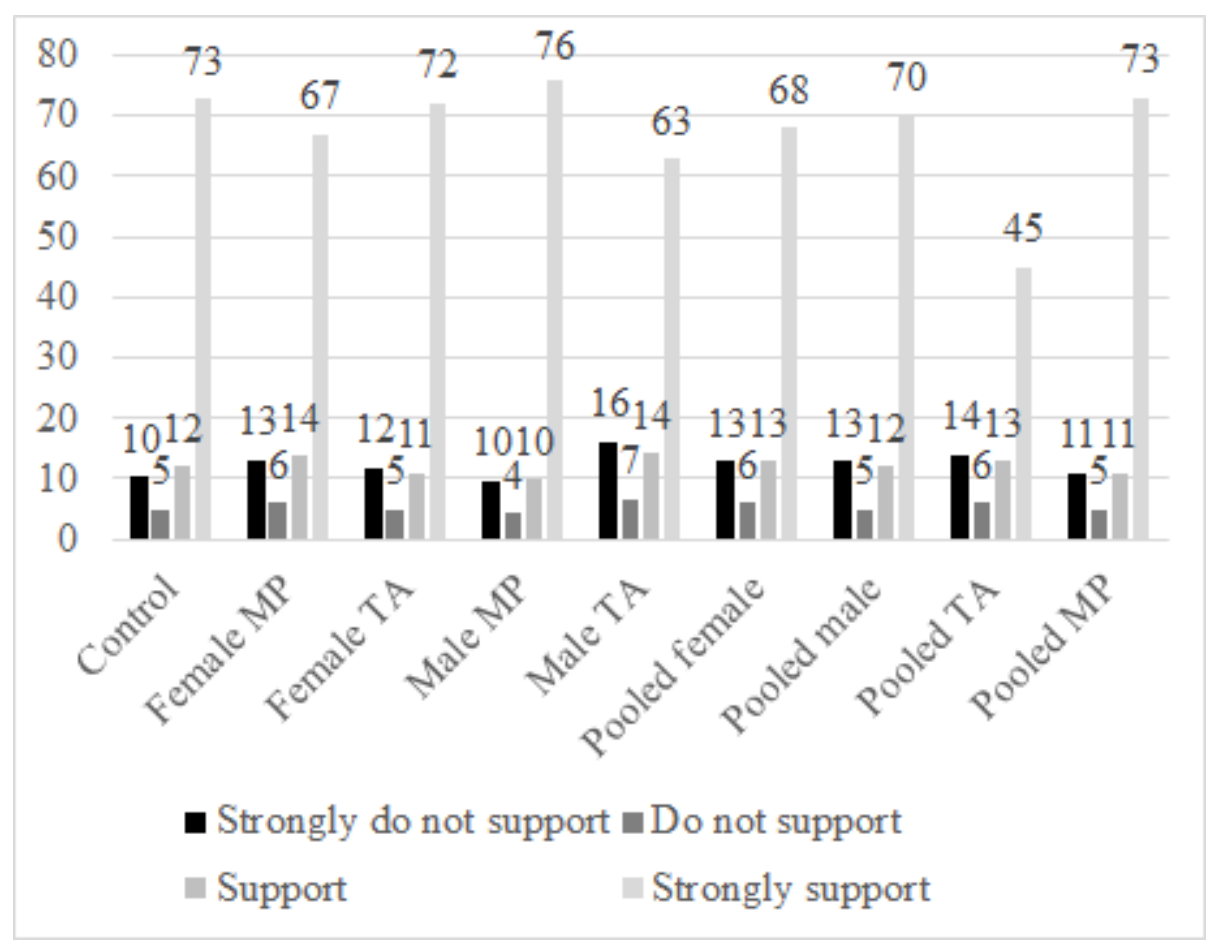

Figure 8 shows predicted probability of supporting the law among citizens with patrilineal and matrilineal customs. 
Table 5. Significance levels for pairwise comparisons (patrilineal)

\begin{tabular}{|c|c|c|c|c|}
\hline & Strongly do not support & Do not support & Support & Strongly support \\
\hline \multicolumn{5}{|c|}{ Comparisons of treatments with control } \\
\hline Female MP vs. control (2 vs. 1 ) & 0.493 & 0.498 & 0.487 & 0.481 \\
\hline Female TA vs. control (3 vs. 1) & 0.787 & 0.975 & 0.785 & 0.968 \\
\hline Male MP vs. control (4 vs. 1 ) & 0.868 & 0.633 & 0.399 & 0.648 \\
\hline Male TA vs. control (5 vs. 1 ) & 0.182 & 0.300 & 0.347 & 0.227 \\
\hline \multicolumn{5}{|c|}{ Comparisons of institutions (State vs. traditional) } \\
\hline Female TA vs. MP (3 vs. 2) & 0.792 & 0.432 & 0.298 & 0.559 \\
\hline Male TA vs. MP (5 vs. 4) & $.036 *$ & $.020^{*}$ & $.003 * *$ & $.005^{* *}$ \\
\hline \multicolumn{5}{|c|}{ Comparisons of gender (Female vs. male) } \\
\hline Male vs. female MP (4 vs. 2) & 0.272 & $.087 \dagger$ & $.012 *$ & $.083 \dagger$ \\
\hline Male vs. female TA (5 vs. 3) & .412 & 0.230 & 0.273 & 0.316 \\
\hline \multicolumn{5}{|l|}{ Other comparisons } \\
\hline Male TA vs. female MP (5 vs. 2) & .426 & 0.563 & 0.769 & 0.497 \\
\hline Male MP vs. female TA (4 vs. 3) & 0.679 & 0.729 & 0.680 & 0.679 \\
\hline \multicolumn{5}{|l|}{ Pooled comparisons (Gender) } \\
\hline Female vs. control (2 vs. 1 ) & 0.483 & 0.452 & 0.430 & 0.451 \\
\hline Male vs. control (3 vs. 1) & 0.407 & 0.465 & 0.538 & 0.450 \\
\hline Male vs. female (3 vs. 2) & 0.798 & 0.681 & 0.466 & 0.693 \\
\hline \multicolumn{5}{|l|}{ Pooled comparisons (Institution) } \\
\hline TA vs. control (2 vs. 1 ) & 0.210 & 0.130 & 0.136 & 0.148 \\
\hline MP vs. control (3 vs. 1) & $0.060 \dagger$ & $0.076 \dagger$ & $0.580 \dagger$ & $0.046^{*}$ \\
\hline MP vs. TA (3 vs. 2) & 0.883 & 0.864 & 0.923 & 0.888 \\
\hline
\end{tabular}

${ }^{* * *} \mathrm{p}<.001,{ }^{* *} \mathrm{p}<.01,{ }^{*} \mathrm{p}<.05, \dagger \mathrm{p}<.10$.

Examining pooled results (Table 5), we find that among patrilineal citizens, there is no difference in male versus female comparisons, and the MPs are less effective than the control (a 
backfire effect) $(\mathrm{p}<.05)$. Among this group of respondents, the impact of the authority type depends on the authority's gender.

The size of the backfire effects in the heterogeneous effects analysis seems the same as across the entire sample. However, we find that for matrilineal respondents, endorsements by male MPs are not only the least effective, but they elicit a backfire effect, relative to the control. Among matrilineal citizens_-who are least likely to place trust in male authorities, the male MP elicits lower support (73\%) than the control (86\%), significant at the $\mathrm{p}<.01$ level. This is consistent with H7ii, which anticipates several possible backfire effects. We find no support for biased assimilation in the study.

\section{Summary of Findings}

From these findings, we draw two conclusions (see Table 6). First, we find that TAs may be effective as messengers of women's rights reforms among some population subgroups. Yet, their effectiveness depends on their gender, with female TAs often more effective than male TAs. Drawing on gender role congruity and institutional trust theories, we argue that the female TA's relative effectiveness compared to the other authorities is due to high public trust in TAs, coupled with women's stereotyped competence in the area of women's rights. Moreover, the female TA is the only authority type that does not create a backfire effect. The female TA produces the higher support in the sample as a whole and among female and matrilineal citizens. However, the female TA is not significantly more effective than the female MP. This suggests support for H2 (gendered policy competence) and H3 (intersectional hypothesis).

Second, we find that the effectiveness of the messengers depends on the population subgroup, according to their level of trust in and gender role congruity views concerning the four 
endorsers. While the male MP is less effective than both female messengers among matrilineal citizens $(\mathrm{p}<.05)$, he was the most effective messenger among patrilineal citizens (though the difference is significant only in relation to the male TA, $\mathrm{p}<.01$ ). While we found no support for biased assimilation (H6) when comparing the endorsements to the control, we found evidence for a backfire effect among matrilineal respondents (H7ii), for whom the male MP's endorsement decreased support relative to the control $(\mathrm{p}<.05)$

Taken together, these results show that the impact of the messenger depends on the intersection of authority type and authority gender, as well as on the type of respondent. They also raise the specter of backfire effects — the possibility of doing harm. 
Table 6. Summary of results

\begin{tabular}{|c|c|c|c|c|}
\hline & $\begin{array}{l}\text { Most effective } \\
\text { endorser }\end{array}$ & $\begin{array}{l}\text { Treatments } \\
\text { relative to } \\
\text { one another }\end{array}$ & $\begin{array}{l}\text { Treatments } \\
\text { relative to } \\
\text { control } \\
\text { (backfire) }\end{array}$ & $\begin{array}{l}\text { Treatments } \\
\text { relative to } \\
\text { control } \\
\text { (biased } \\
\text { assimilation) }\end{array}$ \\
\hline $\begin{array}{l}\text { Average treatment } \\
\text { effects }\end{array}$ & $\begin{array}{l}\text { Female TA, though } \\
\text { not significantly } \\
\text { more than any } \\
\text { other treatment or } \\
\text { the control }\end{array}$ & - & $\begin{array}{l}\text { Female MP } \\
(\mathrm{p}<.05), \text { male } \\
\mathrm{MP}(\mathrm{p}<.10), \\
\text { and male TA } \\
(\mathrm{p}<.10) \\
\text { backfire } \\
\text { relative to } \\
\text { control }\end{array}$ & - \\
\hline \multicolumn{5}{|l|}{$\begin{array}{l}\text { Heterogeneous } \\
\text { treatment effects }\end{array}$} \\
\hline Female respondents & $\begin{array}{l}\text { Female TA, though } \\
\text { not significantly } \\
\text { more than the } \\
\text { control, female MP, } \\
\text { or male MP }\end{array}$ & $\begin{array}{l}\text { Female TA } \\
\text { more } \\
\text { effective than } \\
\text { male TA } \\
(\mathrm{p}<.05)\end{array}$ & - & - \\
\hline Male respondents & - & - & - & - \\
\hline Matrilineal respondents & $\begin{array}{l}\text { Female TA, though } \\
\text { not significantly } \\
\text { more than the } \\
\text { control, female MP, } \\
\text { male MP, or male } \\
\text { TA }\end{array}$ & $\begin{array}{l}\text { Female MP } \\
\text { and female } \\
\text { TA more } \\
\text { effective than } \\
\text { male MP } \\
(\mathrm{p}<.05)\end{array}$ & $\begin{array}{l}\text { Male MP } \\
(\mathrm{p}<.001) \\
\text { backfire } \\
\text { relative to } \\
\text { control }\end{array}$ & \\
\hline Patrilineal respondents & $\begin{array}{l}\text { Male MP, though } \\
\text { not significantly } \\
\text { more than the } \\
\text { control, female MP, } \\
\text { or female TA }\end{array}$ & $\begin{array}{l}\text { Male MP } \\
\text { more } \\
\text { effective than } \\
\text { male TA } \\
(\mathrm{p}<.01)\end{array}$ & - & - \\
\hline
\end{tabular}

\section{CONCLUSION}

Both scholars and policymakers grapple with the questions of when and how TAs provide effective governance in support of development and human rights goals. The results of our survey experiment suggest that the answers depend on the authority’s gender and citizens' 
characteristics. We find that under particular circumstances, TAs can be more effective endorsers of policy messages than MPs. This is the case for female TAs in the sample as a whole, as well as among women, those who follow matrilineal customs, and those who hold supportive attitudes about gender equality.

At the same time, our analysis suggests that the gender of the TA is important. For a gender-sensitive child marriage reform law, female TAs and female MPs are more effective than their male counterparts in the sample as a whole, as well as among women, those who follow matrilineal customs, and those who hold supportive attitudes about gender equality. More research is needed to compare the impact of these types of authorities across policies associated with the stereotyped competencies of male and female leaders.

Our findings have important implications for the growing body of research on traditional governance, which we extend by demonstrating the need for an intersectional theory of policy advocacy. If traditional leaders are increasingly being seen as partners in development we need more research into how different background characteristics such as age, gender, education, and political engagement may affect both their capacity to carry out reforms and to what extent they are seen as relevant drivers of change in their communities. This research could form the basis for developing new theories of how and when traditional leaders may serve to promote or impede change. This is particularly critical within the area of gender law reform where we need more studies to further establish how traditional and political institutions complement one another for more effective policy implementation.

Our findings also have implications for international agencies, national governments, and civil-society organizations across the developing world that champion human rights initiatives and provide traditional leaders with a significant role in the implementation of such reform 
initiatives. Traditional leaders can play a constructive role in brokering infrastructure development projects, as well as projects aimed at enhancing gender equality. Yet, their impact is complex in a society such as Malawi’s, whose diverse ethnic and societal practices mirror most of Africa. Among some groups, male leaders can be effective, while in others, women are better placed to play this role.

Some cautions are in order. The presence of traditional institutions might not always be positive; they may sometimes undermine the role of elected representatives and the consolidation of democracy. In the long run, this could become detrimental to women's rights and empowerment. Several actors can be effective endorsers among different groups, but they also have the potential to do harm when the wrong authority pushes a policy that one or more groups see as running counter to their interests and not falling within the authority's supposed competencies. Rights concerning gender equality, sexuality, and reproduction are policy areas that are sensitive to prior beliefs and backfire effects, and reform promotion applying the “wrong” messenger could impact the support of the reform significantly. This underscores the need to gather context-specific information and to develop an effective strategy for engaging citizens positively with different leaders to promote human rights reform. 


\section{References}

Ahluwalia, R. (2000). Examination of psychological processes underlying resistance to persuasion. Journal of Consumer Research, 27(2), 217-232. DOI: 10.1086/314321.

Arceneaux K., \& Kolodny, R. (2009). Educating the least informed: Group endorsements in a grassroots campaign. American Journal of Political Science, 53(4), 755-770. doi:10.1111/j.1540-5907.2009.00399.x.

Baldwin, K. (2016). The paradox of traditional chiefs in democratic Africa. New York, NY: Cambridge University Press.

Bank, L., \& Southall, R. (1996). Traditional leaders in South Africa’s new democracy. The Journal of Legal Pluralism and Unofficial Law, 28(37-38), 407-430.

Bauer. G. (2016). 'What is wrong with a woman being chief?’ Women Chiefs and Symbolic and Substantive Representation in Botswana. Journal of Asian and African Studies, 51(2): 222-237. doi: 10.1177/0021909614545700

Bauer, G. \& Burnet, J. (2013) Gender quotas, democracy and women’s representation in Africa: Some insights from democratic Botswana and autocratic Rwanda. Women’s Studies International Forum 41(2): 103-112. doi:10.1016/j.wsif.2013.05.012.

Bauer, G. (2012). 'Let there be a balance’: Women in African parliaments. Political Studies Review, 10(3), 370-384. doi:10.1111/j.1478-9302.2012.00272.x.

Benstead, L. J. (2014). “Effects of interviewer-respondent gender interaction on attitudes toward women and politics: Findings from Morocco.” International Journal of Public Opinion Research 26(3), 369-383. First published online September 27, 2013. doi: 10.1093/ijpor/edt024. 
Benstead, L. J., Jamal, A.A., \& Lust, E. (2015). Is it gender, religiosity or both? A role congruity theory of candidate electability in transitional Tunisia. Perspectives on Politics, 13(1), 74-94.

Bilz, K., \& Nadler, J. (2014). Law, Moral Attitudes, and Behavioral Change. In E. Zamir, \& D. Teichman (Eds.), The Oxford Handbook of Behavioral Economics and the Law, (241267). Oxford: Oxford University Press.

Bush, S.S., \& Jamal, A.A. (2015) Anti-Americanism, authoritarian politics, and attitudes about women’s representation: Evidence from a survey experiment in Jordan. International Studies Quarterly, 59(1), 34-45. doi: 10.1111/isqu.12139

Calvo, E. (2007). The responsive Legislature: Public Opinion and Law Making in a Highly Disciplined Legislature. British Journal of Political Science, 37, 263-280.

Cammack, D., Kanyongolo, E., \& O’Neill, T. (2009). “Town chiefs” in Malawi. Working paper no. 3, Africa power and politics, London: Overseas Development Institute.

Carmines, E. G., \& Kuklinski, J. H. (1990). Incentives, opportunities, and the logic of public opinion in American political representation. In J. A. Ferejohn \& J. H. Kuklinski (Eds.), Information and democratic processes (240-268). Champaign, IL: University of Illinois Press.

Charrad, M. (2001). States and women's rights: The making of postcolonial Tunisia, Algeria, and Morocco. Berkeley, CA: University of California Press.

Chimjeka, R. (2016, January 2). Snatched from the jaws: Malawi abolishes 600,000 child marriages. The Nation. Retrieved from: http://mwnation.com/snatched-from-the-jawsmalawi-abolishes-600-000-child-marriages/. 
Clayton, A. (2014). Electoral gender quotas and attitudes toward traditional leaders: A policy experiment in Lesotho. Journal of Policy Analysis and Management, 33(4), 1007-26. doi: 10.1002/pam.21789.

Cloward, K. (2014). False commitments: Local misrepresentation and the international norms against female genital mutilation and early marriage. International Organization, 68(3), 495-526.

Díaz-Cayeros, A., Magaloni, B., \& Alexander, R. E. (2014). Traditional governance, citizen engagement and local public goods: Evidence from Mexico. World Development, 53, 8093. doi:http://dx.doi.org/10.1016/j.worlddev.2013.01.008.

Ditto, P. H., \& Lopez, D. F. (1992). Motivated skepticism: Use of differential decision criteria for preferred and nonpreferred conclusions. Journal of Personality and Social Psychology, 63(4), 568-584. Retrieved from https://www.unc.edu/ fbaum/teaching/articles/jpsp-1992-Ditto.pdf".

Dolan, K., \& Sanbonmatsu, K, (2011). Candidate gender and experimental political science. In J. Druckman, D. Green, J. H. Kuklinski,\& A. Lupia (Eds.), Handbook of experimental political science (289-298). Cambridge: Cambridge University Press.

Dulani, B., \& Dionne, K.Y. (2014). Presidential, parliamentary, and local government elections in Malawi, May 2014. Electoral Studies, 36(4), 218-225.

Dragojlovic, N. (2015). Listening to Outsiders: The Impact of messenger nationality on transnational persuasion in the United States. International Studies Quarterly, 59 (1), 7385. 
Eagly, A. H., \& Diekman, A. B. (2006). Examining gender gaps in sociopolitical attitudes: It's not Mars and Venus. Feminism \& Psychology, 16(1), 26-34. doi: 10.1177/0959353506060817.

Eagly, A. H., \& Karau, S. J. (2002). Role congruity theory of prejudice toward female leaders. Psychological Review, 109(3), 573-598. doi: 10.1037//0033-295X.109.3.573

Edwards, K., \& Smith, E. E. (1996). A disconfirmation bias in the evaluation of arguments. Journal of Personality and Social Psychology, 71(1), 5-24. doi: 10.1037/00223514.71.1.5.

Englebert, P. (2000). State and legitimacy and development in Africa. Boulder: Lynne Rienner Publishers.

Franceschet, S., Krook, M.L., \& Piscopo, J.M. (2012). The impact of gender quotas. Oxford: Oxford University Press.

Goren, P., Frederico, C., M.F., \& Kittilson, M. C. (2009). Source cues, partisan identities, and political value expression. American Journal of Political Science, 53(4), 805-820. doi: 10.1111/j.1540-5907.2009.00402.x

Holzinger, K., Kern, F. G., \& Kromrey, D. (2016). The dualism of contemporary traditional governance and the state: Institutional setups and political consequences. Political Research Quarterly, 69(3), 469-481.

Htun, M., \& Weldon, L. (2010). When do governments promote women’s rights? A framework for the comparative analysis of sex equality policy: A comparative politics of gender. Perspectives on Politics, 8(1), 207-216.doi:10.1017/S1537592709992787.

Htun, M., \& Weldon, L. (forthcoming). States and the logics of gender justice. Cambridge: Cambridge University Press. 
Hudson, V. M., Bowen, D. L., \& Nielsen, P. L. (2015). Clan governance and state stability: The relationship between female subordination and political order. American Political Science Review, 109(03), 535-555. doi:10.1017/S0003055415000271.

Huddy, L., \& Therkildsen, N. (1993). Gender stereotypes and the perception of male and female candidates. American Journal of Political Science, 37(1), 119-147. doi: $10.2307 / 2111526$.

Inter-Parliamentary Union. (2017). Women in National Parliaments. http://www.ipu.org/wmn-e/arc/world011216.htm.

Kachali, R. (2013, November 4). Malawi chiefs want marriage age at 21. The Nation. Retrieved from: http://mwnation.com/malawi-chiefs-want-marriage-age-at-21/.

Kang, A. (2015). Bargaining for women's rights. Activism in an aspiring Muslim democracy. Minneapolis: University of Minnesota Press.

Kaarhus, R. (2010) Women’s land rights and land tenure reforms in Malawi: What difference does Matriliny make? Forum for Development Studies 37(2), 171-192. doi: $10.1080 / 08039411003725857$

King, D. \& Matland, R. (2002). Women as candidates in congressional elections. In C.S. Rosenthal (Ed.) (119-145). Women transforming congress, l. Norman: University of Oklahoma Press.

Kunda, Z. (1990). The case for motivating reasoning. Psychological Bulletin, 108(3), 480-98. doi: http://dx.doi.org/10.1037/0033-2909.108.3.480.

Lawless, J. (2004). Women, war, and winning elections: Gender stereotyping in the postSeptember 11th Era. Political Research Quarterly (Formerly WPQ), 57(3), 479-490. Logan, C. (2009). Selected chiefs, elected councilors, and hybrid democrats: Popular 
perspectives on the co-existence of democracy and traditional authority. Journal of Modern African Studies, 47(1), 101-128.

Long, J. S., \& Freese, J. (2014). Regression models for categorical dependent variables using stata. (3rd ed.). College Station, TX: Stata Press.

Lord, C. G., Ross, L., \& Lepper, M. R. (1979). Biased assimilation and attitude polarization: The effects of prior theories on subsequently considered evidence. Journal of Personality and Social Psychology, 37(11), 2098-2109.

Mamdani, M. (1996). Citizen and subject: Contemporary Africa and the legacy of late colonialism. Kampala: Fountain Publishers.

Masoud, T., Jamal, A., \& Nugent, E. (2016). Using the Qur'ān to empower Arab women? Theory and experimental evidence from Egypt. Comparative Political Studies, 49(12), 1555-98. doi: 10.1177/0010414015626452.

Mensah, C. A., Antwi, K. B., \& Suleman, D. (2014). Female traditional leaders (queen mothers) and community planning and development in Ghana. Environmental management and sustainable development, 3(1), 205-220. doi:10.5296/emsd.v3i1.5142.

Mijiga, F. (1998). The role of traditional leaders in a democratic dispensation. National Democratic Institute. Retrieved from: https://www.ndi.org/files/027_ww_tradleaders.pdf, 5 January 2017.

Miller, A. G., McHoskey, J. W., Bane, C. M., \& Dowd, T. G. (1993). The attitude polarization phenomenon: Role of response measure, attitude extremity, and behavioral consequences of reported attitude change. Journal of Personality and Social Psychology, 64(4), 561574. doi: 10.1037/0022-3514.64.4.561. 
Molden, D.C., \& Higgins, E.T. (2005). Motivated thinking. In K.J. Holyoakand \& R.G. Morrison (Eds.). The Cambridge handbook of thinking and reasoning (295-317), Rochester, NY: Cambridge University Press.

Mondak, J. (1993). Source cues and policy approval: the cognitive dynamics of support for the Reagan agenda. American Journal of Political Science, 37(1), 186-212. Doi: $10.2307 / 2111529$.

Munro, G. D., Ditto, P. H., Lockhart, L. K., Fagerlin, A., Gready, M., \& Peterson, E. (2002). Biased assimilation of sociopolitical arguments: Evaluating the 1996 U.S. Presidential debate. Basic and Applied Social Psychology, 24(1), 15-26. Doi: 10.1207/S15324834BASP2401_2

Muriaas, R., Tønnessen, L., \& Wang, V. (2018). Counter-mobilization against child marriage reform in Africa. Political Studies, online first. Doi: 10.1177/0032321717742859

Mutz, D. C. (2011). Population-based survey experiments. Princeton, NJ: Princeton University Press.

Nyhan, B. \& Reifler, R. (2010). When corrections fail: The persistence of political misperceptions. Political Behavior, 32(2), 303-330.

Panos 2015. “On Ending Child Marriages in Malawi” Media Brief. Lusaka: Panos Institute Southern Africa. Retrieved from http://www.africanchildinfo.net/index.

Peters, P. E. (1997). Against the Odds: Matriliny, land and gender in the Shire Highlands of Malawi. Critique of Anthropology, 17(2), 189-210.

Phiri, K. M. (1983). Some Changes in the matrilineal family system among the Chewa of Malawi since the nineteenth century. The Journal of African History, 24 (02), 257-274. 
Posner, D. (2004). The political salience of cultural difference: Why Chewas and Tumbukas are allies in Zambia and adversaries in Malawi. American Political Science Review, 98(4), $529-545$.

Rosenwasser, S. M., \& Seale, J. (1988). Attitudes toward a hypothetical male or female presidential candidate-A research note. Political Psychology, 9(4), 591-598.

Tamale, S. (1999) When hens begin to crow. Boulder, CO: Westview Press.

Toyo, N. (2006). Revisiting equality as a right: The minimum age of marriage clause in the Nigerian child rights act, 2003. Third World Quarterly, 27 (7), 1299-1312.

UNFPA. (2012). Marrying too young. End child marriage. New York, New York: United Nations Population Fund. Retrieved from: https:/www.unfpa.org/sites/default/files/pubpdf/MarryingTooYoung.pdf.

UNICEF. (2015). The state of the world's children 2015. New York: United Nation Children's Fund. Retrieved from: http://www.unicef.org/publications/index_77928.html

Villalón, L. A. (2010). From argument to negotiation: Constructing democracy in African Muslim context. Comparative Politics, 42 (4), 375-393.

Weber, C., Dunaway, J. \& Johnson T. (2012). It's all in the name: Source cue ambiguity and the persuasive appeal of campaign ads. Political Behavior, 34 (3), 561-584.

Wang, V. (2013). Women changing policy outcomes: Learning from pro-women legislation in the Ugandan Parliament. Women’s Studies International Forum, 41, 113-121.

WLSA \& NGOGCN Malawi NGO Gender Coordinating Network (2009). A shadow report to the Malawi Government sixth periodic report on the implementation of the convention on the elimination of all forms of discrimination against women. Retrieved from http://www2.ohchr.org/english/bodies/cedaw/docs/ngos/WLSAMalawi45_session.pdf 
Zuwerink, J., \& Devine, P. G. (1996). Attitude importance and resistance to persuasion: It’s not just the thought that counts. Journal of Personality and Social Psychology, 70(5), 931944. doi: 10.1037/0022-3514.70.5.931 


\section{Appendix}

\section{Appendix 1: Randomization Checks and Question Wording for Independent Variables}

A randomized block design was used. All test showed that randomization was effective. In order to reduce questionnaire length, a random subset of the 7,750 respondents in the LGPI took part in the experiment. Table A1.1 shows that the 1,381 respondents who received the child marriage endorsement study embedded in the LGPI were randomly distributed across the 15 electoral districts $(\mathrm{p}<.422)$.

Table A1.1. Randomized block design: Selection of respondents to take part in child marriage endorsement experiment

\begin{tabular}{|l|c|c|c|}
\hline & Respondents not selected & Respondents selected & Total \\
\hline Balaka & $307(85.3 \%)$ & $53(14.7 \%)$ & $360(100.0 \%)$ \\
\hline Blantyre & $571(81.6 \%)$ & $129(18.4 \%)$ & $700(100.0 \%)$ \\
\hline Chikwawa & $572(80.5 \%)$ & $139(19.6 \%)$ & $711(100.1 \%)$ \\
\hline Chitipa & $289(82.1 \%)$ & $63(17.95)$ & $352(100.0 \%)$ \\
\hline Dedza & $573(80.4 \%)$ & $140(19.6 \%)$ & $713(100.0 \%)$ \\
\hline Kasungu & $280(85.6 \%)$ & $47(14.4 \%)$ & $327(100.0 \%)$ \\
\hline Lilongwe & $595(83.6 \%)$ & $117(16.4 \%)$ & $712(100.0 \%)$ \\
\hline Mangochi & $281(81.7 \%)$ & $63(18.3 \%)$ & $344(100.0 \%)$ \\
\hline Mulanje & $294(82.6 \%)$ & $62(17.4 \%)$ & $356(100.0 \%)$ \\
\hline Mzimba & $1,144(81.4 \%)$ & $262(18.6 \%)$ & $1,406(100.0 \%)$ \\
\hline Nkhatabay & $293(84.0 \%)$ & $56(16.1 \%)$ & $349(100.1 \%)$ \\
\hline Nsanje & $281(79.4 \%)$ & $73(20.6 \%)$ & $354(100.0 \%)$ \\
\hline Ntcheu & $293(84.2 \%)$ & $55(15.8 \%)$ & $348(100.0 \%)$ \\
\hline Rumphi & $300(84.0 \%)$ & $57(16.0 \%)$ & $357(100.0 \%)$ \\
\hline Zomba & $295(81.9 \%)$ & $65(18.1 \%)$ & $360(100.0 \%)$ \\
\hline Total & $6,368(82.2 \%)$ & $1,381(17.8 \%)$ & $7,749(100.0 \%)$ \\
\hline
\end{tabular}

Two-tailed $\chi^{2}$ test shows treatments are randomly distributed across electoral districts $(\mathrm{p}<.422)$.

Table A1.2 shows that the 1,381 respondents who were selected to take part in the experiment were randomly assigned to either the control or the four treatment groups $(\mathrm{p}<.891)$.

Table A1.2. Randomized block design: Assignment of respondents to control and experimental conditions 


\begin{tabular}{|l|c|c|c|c|c|c|}
\hline & Control & Female MP & Female TA & Male MP & Male TA & Total \\
\hline Balaka & $15(28.3 \%)$ & $6(11.3 \%)$ & $8(15.1 \%)$ & $11(20.8 \%)$ & $13(24.5 \%)$ & $53(100.0 \%)$ \\
\hline Blantyre & $24(18.6 \%)$ & $22(17.1 \%)$ & $26(20.2 \%)$ & $28(21.7 \%)$ & $29(22.5 \%)$ & $129(100.1 \%)$ \\
\hline Chikwawa & $31(22.3 \%)$ & $25(18.0 \%)$ & $23(16.6 \%)$ & $33(23.7 \%)$ & $27(19.4 \%)$ & $139(100.0 \%)$ \\
\hline Chitipa & $15(23.8 \%)$ & $13(20.6 \%)$ & $16(25.4 \%)$ & $12(19.1 \%)$ & $7(11.1 \%)$ & $63(100.0 \%)$ \\
\hline Dedza & $29(20.7 \%)$ & $22(15.7 \%)$ & $28(20.0 \%)$ & $31(22.1 \%)$ & $30(21.4 \%)$ & $140(99.9 \%)$ \\
\hline Kasungu & $5(10.6 \%)$ & $10(21.3 \%)$ & $6(12.8 \%)$ & $12(25.5 \%)$ & $14(29.8 \%)$ & $47(100.0 \%)$ \\
\hline Lilongwe & $21(18.0 \%)$ & $24(20.5 \%)$ & $24(20.5 \%)$ & $21(18.0 \%)$ & $27(23.1 \%)$ & $117(100.1 \%)$ \\
\hline Mangochi & $10(15.9 \%)$ & $13(20.6 \%)$ & $12(19.1 \%)$ & $18(28.6 \%)$ & $10(15.9 \%)$ & $63(100.1 \%$ \\
\hline Mulanje & $9(14.5 \%)$ & $15(24.2 \%)$ & $15(24.2 \%)$ & $10(16.1 \%)$ & $13(21.0 \%)$ & $62(100.0 \%)$ \\
\hline Mzimba & $59(22.5 \%)$ & $60(22.9 \%)$ & $54(20.6 \%)$ & $41(15.7 \%)$ & $48(18.3 \%)$ & $262(100.0 \%)$ \\
\hline Nkhatabay & $12(21.4 \%)$ & $9(16.1 \%)$ & $15(26.8 \%)$ & $8(14.3 \%)$ & $12(21.4 \%)$ & $56(100.0 \%)$ \\
\hline Nsanje & $20(27.4 \%)$ & $16(21.9 \%)$ & $15(20.6 \%)$ & $10(13.7 \%)$ & $12(16.4 \%)$ & $73(100.0 \%)$ \\
\hline Ntcheu & $11(20.0 \%)$ & $9(16.4 \%)$ & $12(21.8 \%)$ & $10(18.2 \%)$ & $13(23.6 \%)$ & $55(100.0 \%)$ \\
\hline Rumphi & $13(22.8 \%)$ & $10(17.5 \%)$ & $10(17.5 \%)$ & $9(15.8 \%)$ & $15(26.3 \%)$ & $57(99.9 \%)$ \\
\hline Zomba & $10(15.4 \%)$ & $15(23.1 \%)$ & $11(16.9 \%)$ & $15(23.1 \%)$ & $14(21.5 \%)$ & $65(100.0 \%)$ \\
\hline Total & $284(20.6 \%)$ & $269(19.5 \%)$ & $275(19.9 \%)$ & $269(19.5 \%)$ & $284(20.6 \%)$ & $1,381(100.1 \%)$ \\
\hline
\end{tabular}

Two-tailed $\chi^{2}$ test show treatments are randomly distributed across electoral districts $(\mathrm{p}<.891)$.

There were no differences in response rates (i.e., attrition rates) across the five conditions. Only 12 respondents did not provide an answer on the dependent variable and missing data was not related to condition.

Table A1.3 shows that the conditions were randomly distributed across demographic variables, as shown by insignificant chi-square tests. Question wording and descriptive statistics for all independent variables are also given.

Table A1.3. Randomization of treatment and descriptive statistics for independent variables

\begin{tabular}{|c|c|c|c|c|c|}
\hline & Control & Female MP & Female TA & Male MP & Male TA \\
\hline \multicolumn{6}{|l|}{ Gender } \\
\hline Male & $22.3 \%$ & $18.2 \%$ & $18.8 \%$ & $19.2 \%$ & $21.5 \%$ \\
\hline Female & $19.7 \%$ & $20.2 \%$ & $20.5 \%$ & $19.6 \%$ & $20.0 \%$ \\
\hline$(N=1,378 /$ Mean $=.65 / S d=.48)$ & \multicolumn{5}{|c|}{$\chi 2(4)=2.4283(\mathrm{p}<.658)$} \\
\hline \multicolumn{6}{|l|}{ Interviewer gender } \\
\hline Male & $19.4 \%$ & $18.9 \%$ & $20.8 \%$ & $20.3 \%$ & $20.6 \%$ \\
\hline Female & $22.2 \%$ & $20.3 \%$ & $18.7 \%$ & $18.4 \%$ & $20.4 \%$ \\
\hline$(N=1,377 / \mathrm{Mean}=.42 / \mathrm{Sd}=.49)$ & \multicolumn{5}{|c|}{$\chi 2(4)=2.8524(p<.583)$} \\
\hline Gender role congruent views ${ }^{1}$ & & & & & \\
\hline Prefer male & $17.1 \%$ & $14.1 \%$ & $20.1 \%$ & $24.2 \%$ & $24.5 \%$ \\
\hline
\end{tabular}




\begin{tabular}{|c|c|c|c|c|c|}
\hline Prefer male or no difference & $20.8 \%$ & $19.6 \%$ & $20.2 \%$ & $18.9 \%$ & $21.0 \%$ \\
\hline Prefer female & $23.0 \%$ & $22.3 \%$ & $19.5 \%$ & $17.7 \%$ & $17.6 \%$ \\
\hline$(N=1,350 /$ Mean $=.43 / S d=.49)$ & \multicolumn{5}{|c|}{$\chi 2(4)=10.3154(p<.021)^{*}$} \\
\hline \multicolumn{6}{|l|}{ Patrilineal/Matrilineal $^{1}$} \\
\hline Does not pay lobola (Matrilineal) & $19.5 \%$ & $17.6 \%$ & $18.2 \%$ & $22.1 \%$ & $22.7 \%$ \\
\hline Pay lobola (Patrilineal) & $21.9 \%$ & $21.2 \%$ & $21.5 \%$ & $17.0 \%$ & $18.4 \%$ \\
\hline$(N=1,368 /$ Mean $=.49 / S d=.50)$ & \multicolumn{5}{|c|}{$\chi 2(4)=12.6223(\mathrm{p}<.013)^{*}$} \\
\hline \multicolumn{6}{|l|}{ Economic status $^{2}$} \\
\hline First quartile & $20.8 \%$ & $18.9 \%$ & $19.5 \%$ & $19.3 \%$ & $21.5 \%$ \\
\hline Second quartile & $19.3 \%$ & $21.8 \%$ & $17.5 \%$ & $19.1 \%$ & $22.1 \%$ \\
\hline Third quartile & $24.5 \%$ & $15.9 \%$ & $20.5 \%$ & $21.5 \%$ & $17.6 \%$ \\
\hline Fourth quartile & $18.3 \%$ & $21.1 \%$ & $22.2 \%$ & $18.3 \%$ & $20.1 \%$ \\
\hline$(N=1,368 /$ Mean $=2.30 / S d=1.14)$ & \multicolumn{5}{|c|}{$\chi^{2}(12)=11.1280(\mathrm{p}<.518)$} \\
\hline \multicolumn{6}{|l|}{ Education } \\
\hline No formal schooling & $27.4 \%$ & $17.4 \%$ & $16.4 \%$ & $19.9 \%$ & $18.9 \%$ \\
\hline Some primary school & $18.6 \%$ & $19.1 \%$ & $19.8 \%$ & $20.7 \%$ & $21.8 \%$ \\
\hline Some primary school completed & $23.9 \%$ & $20.0 \%$ & $20.9 \%$ & $17.0 \%$ & $18.5 \%$ \\
\hline Some intermediate school or more & $16.6 \%$ & $22.5 \%$ & $22.5 \%$ & $18.7 \%$ & $19.8 \%$ \\
\hline$(N=1,366 /$ Mean $=2.32 / S d=.89)$ & \multicolumn{5}{|c|}{$\chi^{2}(12)=14.8515(\mathrm{p}<.250)$} \\
\hline \multicolumn{6}{|l|}{ Rural residence $^{4}$} \\
\hline Urban or small town & $17.5 \%$ & $19.8 \%$ & $21.4 \%$ & $19.8 \%$ & $21.4 \%$ \\
\hline Rural & $21.3 \%$ & $19.4 \%$ & $19.5 \%$ & $19.4 \%$ & $20.4 \%$ \\
\hline$(N=1,376 /$ Mean $=.81 / S d=.39)$ & \multicolumn{5}{|c|}{$\chi^{2}(4)=2.0386(\mathrm{p}<.729)$} \\
\hline \multicolumn{6}{|l|}{ Age groups } \\
\hline$<25$ years & $18.2 \%$ & $17.0 \%$ & $20.4 \%$ & $22.5 \%$ & $21.9 \%$ \\
\hline $25-34$ years & $19.3 \%$ & $21.1 \%$ & $18.2 \%$ & $19.5 \%$ & $21.9 \%$ \\
\hline 35-44 years & $23.0 \%$ & $19.3 \%$ & $18.9 \%$ & $20.3 \%$ & $18.6 \%$ \\
\hline$>45$ years & $22.2 \%$ & $20.1 \%$ & $21.6 \%$ & $16.4 \%$ & $19.8 \%$ \\
\hline$(N=1,378 /$ Mean $=2.53 / S d=1.13)$ & \multicolumn{5}{|c|}{$\chi^{2}(12)=10.2369(\mathrm{p}<.595)$} \\
\hline
\end{tabular}

Two-tailed $\chi^{2}$ test show treatments are randomly distributed across groups for all independent and control variables, with the exception of a priori gender attitudes $(\mathrm{p}<.05)$ and lineal customs $(\mathrm{p}<.05) .{ }^{1}$ The higher the value, the more assets a household possesses. How likely would you be to vote for a female candidate in a parliamentary election? Would you be more likely to vote for her than a male (=1/Supports), less likely to vote for her (=0/Opposes), or would you say that there is no difference (=0/Opposes) ${ }^{2}{ }^{2}$ In your family, is lobola [bride price/dowry] paid when people get married? Yes (=0/Patrilineal). No (=1/Matrilineal). ${ }^{3}$ The asset index was created by performing a multiple correspondence analysis on four assets a household could possibly possess: motor vehicle, mobile telephone, radio, and bicycle. ${ }^{4}$ Census designation.

We also conducted additional randomization checks for comparisons between each single (i.e.., female MP, female TA, male MP, and male TA) and pooled condition (i.e., pooled female, pooled male, pooled TA, and pooled MP) and the control and each single and pooled condition with one another to determine whether the conditions are randomly distributed across each pair of conditions. In each comparison, randomization was effective, as shown by insignificant chi square tests of significance, with the following exceptions: (1) there are more patrilineal citizens 
who received the control than the male MP condition $(\mathrm{p}<.027),(2)$ there are more patrilineal citizens who received the control than the pool male (male MP and male TA) condition ( $<<.016)$, (3) there are more patrilineal citizens who received the female MP than the male TA condition $(\mathrm{p}<.009)$, and there are more patrilineal citizens who received the male MP than the male TA condition $(\mathrm{p}<.000)$. For this reason, we include controls for cultural customs in the ordered logistic regressions.

\section{Appendix 2: Regression Models with Controls}

Appendix 2 gives the full ordered logistic regression results for the models reported in the paper, which include control variables: respondent and interviewer gender (Benstead, 2014), whether the respondent follows matrilineal or patrilineal customs, rural residence, age, income quartile, and education level, as well as post-stratification weights. Tables A2.1 and A2.2 give the ordered logistic regression results for the average treatment effects reported in Figure 5 and Table 2, first for all four experimental conditions (Table A2.1) and second for the models pooled by messenger gender and institution (Table A2.2).

Table A2.1. Ordered logistic model for support for child marriage reform: Average treatment effects (Figure 5 and Table 2)

\begin{tabular}{|l|l|}
\hline Variable & $\begin{array}{l}\text { Ordered Logistic Regression Coefficients: } \\
\text { Average Treatment Effects (Figure 5 and } \\
\text { Table 2) }\end{array}$ \\
\hline $\begin{array}{l}\text { Experimental } \\
\text { Condition }\end{array}$ & \\
\hline Female MP (2) & $.04(1.07)$ \\
\hline Female TA (3) & $.60(1.43)$ \\
\hline Male MP (4) & $-.17(.98)$ \\
\hline Male TA (5) & $-1.27(1.00)$ \\
\hline
\end{tabular}




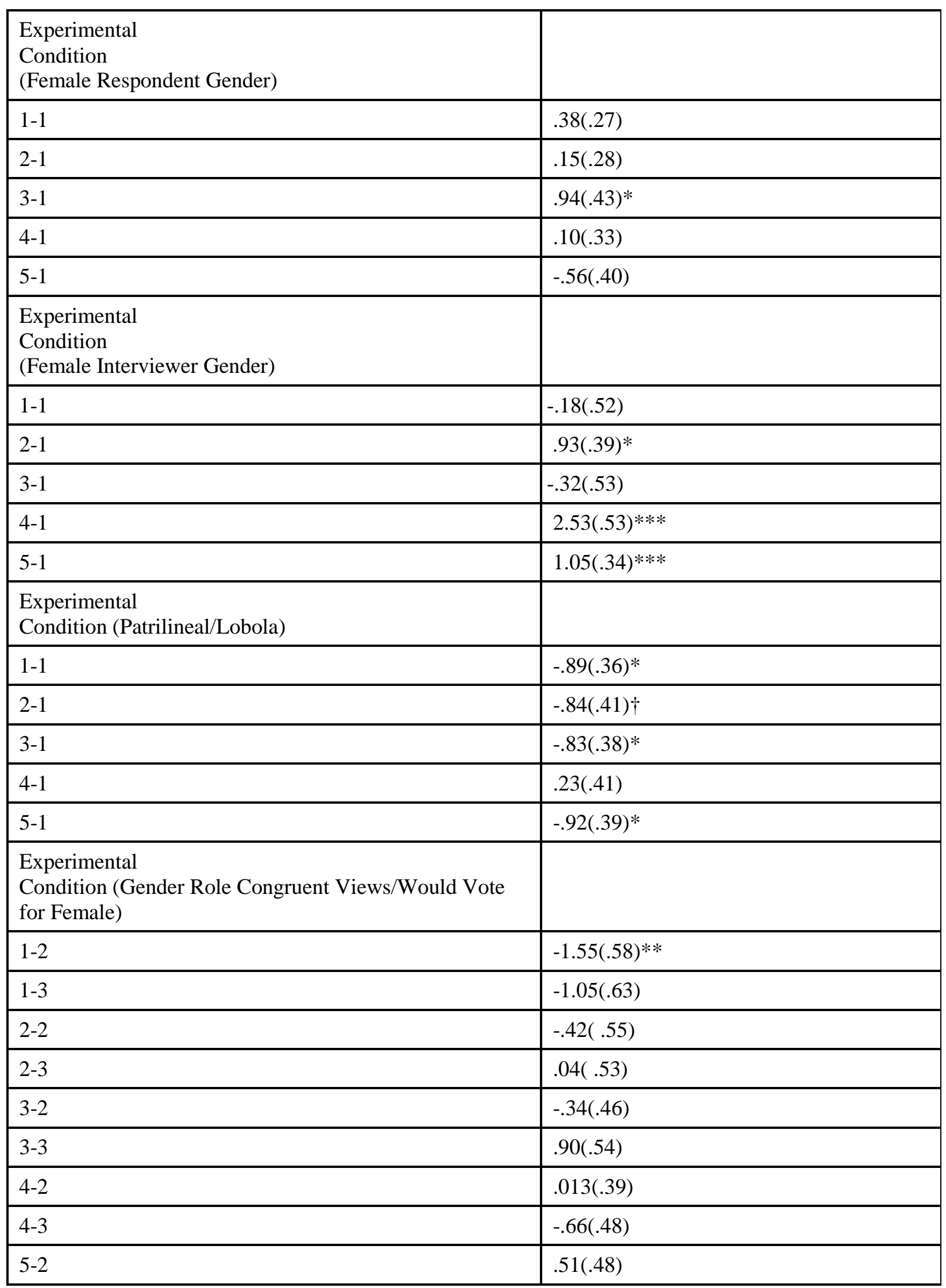




\begin{tabular}{|c|c|}
\hline $5-3$ & $.84(.44)$ \\
\hline \multicolumn{2}{|l|}{$\begin{array}{l}\text { Experimental } \\
\text { Condition (q13_rural) }\end{array}$} \\
\hline $1-1$ & $.24(.54)$ \\
\hline $2-1$ & $-.25(.53)$ \\
\hline $3-1$ & $.45(.58)$ \\
\hline $4-1$ & $-.20(.47)$ \\
\hline $5-1$ & $.44(.52)$ \\
\hline \multicolumn{2}{|l|}{$\begin{array}{l}\text { Experimental } \\
\text { Condition (Education) }\end{array}$} \\
\hline 1 - Some Primary School & $1.05(.52) \dagger$ \\
\hline 1 - Primary School Complete & $.67(.48)$ \\
\hline 1- Intermediate to Post-Secondary & $1.33(.47)^{*}$ \\
\hline 2 - Some Primary School & $-.12(.78)$ \\
\hline 2 - Primary School Complete & $-.03(.79)$ \\
\hline 2 - Intermediate to Post-Secondary & $-.04(.82)$ \\
\hline 3 - Some Primary School & $-.95(.78)$ \\
\hline 3 - Primary School Complete & $-1.13(.76)$ \\
\hline 3 - Intermediate to Post-Secondary & $-1.95(.69)^{*}$ \\
\hline 4 - Some Primary School & $.27(.51)$ \\
\hline 4 - Primary School Complete & $.66(.70)$ \\
\hline 4- Intermediate to Post-Secondary & $.73(.82)$ \\
\hline 5 - Some Primary School & $.39(.46)$ \\
\hline 5 - Primary School Complete & $-.16(.74)$ \\
\hline 5 - Intermediate to Post-Secondary & $.30(.56)$ \\
\hline \multicolumn{2}{|l|}{$\begin{array}{l}\text { Experimental } \\
\text { Condition (MCA1d_quartile) }\end{array}$} \\
\hline $1-2$ & $-.55(.48)$ \\
\hline $1-3$ & $.05(.45)$ \\
\hline $1-4$ & $-.14(.74)$ \\
\hline $2-2$ & $.07(.51)$ \\
\hline $2-3$ & $-.38(.54)$ \\
\hline $2-4$ & $-.94(.59)$ \\
\hline
\end{tabular}




\begin{tabular}{|c|c|}
\hline $3-2$ & $-.64(.64)$ \\
\hline $3-3$ & $-1.13(.61) \dagger$ \\
\hline $3-4$ & $.06(.61)$ \\
\hline $4-2$ & $-1.16(.45)^{*}$ \\
\hline $4-3$ & $-.50(.28) \dagger$ \\
\hline $4-4$ & $-.50(.41)$ \\
\hline $5-2$ & $.25(.45)$ \\
\hline $5-3$ & $-.17(.61)$ \\
\hline $5-4$ & $-.99(.32)^{* *}$ \\
\hline \multicolumn{2}{|l|}{$\begin{array}{l}\text { Experimental } \\
\text { Condition (Age_groups) }\end{array}$} \\
\hline $1-2$ & $.33(.61)$ \\
\hline $1-3$ & $.63(.52)$ \\
\hline $1-4$ & $1.42(.72) \dagger$ \\
\hline $2-2$ & $.84(.34)^{*}$ \\
\hline $2-3$ & $.09(.37)$ \\
\hline $2-4$ & $.54(.42)$ \\
\hline $3-2$ & $.80(.63)$ \\
\hline $3-3$ & $.28(.65)$ \\
\hline $3-4$ & $-.03(.51)$ \\
\hline $4-2$ & $-.48(.38)$ \\
\hline $4-3$ & $-.77(.57)$ \\
\hline $4-4$ & $-.43(.66)$ \\
\hline $5-2$ & $.70(.71)$ \\
\hline $5-3$ & $.62(.79)$ \\
\hline $5-4$ & $.27(.52)$ \\
\hline /cut1 & $-2.69(.75)^{* *}$ \\
\hline /cut2 & $-2.21(.75)^{* *}$ \\
\hline /cut3 & $-1.41(.75) \dagger$ \\
\hline $\mathrm{N}$ & 1334 \\
\hline Population Size & $5,190,307$ \\
\hline Design DF & 19 \\
\hline Number of Strata & 3 \\
\hline
\end{tabular}




\begin{tabular}{|l|l|}
\hline Number of PSUs & 22 \\
\hline Number of Poststrata & 147 \\
\hline Adjusted Wald Test (F) & \\
\hline Female MP-Female TA (2-3) & $\mathrm{F}(1,19)=.09$ \\
\hline Female MP-Male MP (2-4) & $\mathrm{F}(1,19)=.03$ \\
\hline Female MP-Male TA (2-5) & $\mathrm{F}(1,19)=.83$ \\
\hline Female TA-Male MP (3-4) & $\mathrm{F}(1,19)=0.32$ \\
\hline Female TA-Male TA (3-5) & $\mathrm{F}(1,19)=2.17$ \\
\hline Male MP-Male TA (4-5) & $\mathrm{F}(1,19)=.92$ \\
\hline
\end{tabular}

${ }^{* * *} \mathrm{p}<.001,{ }^{* *} \mathrm{p}<.01,{ }^{*} \mathrm{p}<.05, \dagger \mathrm{p}<.10$. Standard errors in parentheses.

Table A2.2. Ordered logistic model for support for child marriage reform: Average treatment effects, Pooled models (Figure 5 and Table 2)

\begin{tabular}{|c|c|c|c|}
\hline Variable & $\begin{array}{l}\text { Ordered Logistic } \\
\text { Regression } \\
\text { Coefficient: } \\
\text { Average Treatment } \\
\text { Effects (Figure } 5 \text { and } \\
\text { Table 2) }\end{array}$ & Variable & $\begin{array}{l}\text { Ordered Logistic } \\
\text { Regression } \\
\text { Coefficient: }\end{array}$ \\
\hline $\begin{array}{l}\text { Experimental } \\
\text { Condition }\end{array}$ & & $\begin{array}{l}\text { Experimental } \\
\text { Condition }\end{array}$ & \\
\hline Female MP (2) & $.29(.89)$ & Female MP (2) & $-.89(.96)$ \\
\hline Female TA (3) & $-1.15(.92)$ & Female TA (3) & $-.59(.83)$ \\
\hline $\begin{array}{l}\text { Experimental } \\
\text { Condition } \\
\text { (Female Respondent } \\
\text { Gender) }\end{array}$ & & $\begin{array}{l}\text { Experimental } \\
\text { Condition } \\
\text { (Female Respondent } \\
\text { Gender) }\end{array}$ & \\
\hline $1-1$ & $.38(.26)$ & $1-1$ & $.38(.26)$ \\
\hline $2-1$ & $.44(.27)$ & $2-1$ & $.08(.22)$ \\
\hline $3-1$ & $-.11(.28)$ & $3-1$ & $.16(.21)$ \\
\hline $\begin{array}{l}\text { Experimental } \\
\text { Condition } \\
\text { (Female Interviewer } \\
\text { Gender) }\end{array}$ & & $\begin{array}{l}\text { Experimental } \\
\text { Condition } \\
\text { (Female Interviewer } \\
\text { Gender) }\end{array}$ & \\
\hline $1-1$ & $-.18(.51)$ & $1-1$ & $-.18(.51)$ \\
\hline $2-1$ & $.21(.25)$ & $2-1$ & $.48(.29)$ \\
\hline $3-1$ & $1.60(.33)^{* * *}$ & $3-1$ & $1.71(.29)^{* * *}$ \\
\hline
\end{tabular}




\begin{tabular}{|c|c|c|c|}
\hline $\begin{array}{l}\text { Experimental } \\
\text { Condition (Lobola) }\end{array}$ & & $\begin{array}{l}\text { Experimental } \\
\text { Condition (Lobola) }\end{array}$ & \\
\hline $1-1$ & $-.88(.36)^{*}$ & $1-1$ & $-.88(.36)^{*}$ \\
\hline $2-1$ & $-1.01(.24)^{* * *}$ & $2-1$ & $-.87(.32)^{*}$ \\
\hline $3-1$ & $-.33(.24)$ & $3-1$ & $-.23(.35)$ \\
\hline $\begin{array}{l}\text { Experimental } \\
\text { Condition (Gender Role } \\
\text { Congruent Views/Would } \\
\text { Vote for Female) }\end{array}$ & & $\begin{array}{l}\text { Experimental } \\
\text { Condition (Gender Role } \\
\text { Congruent Views/Would } \\
\text { Vote for Female) }\end{array}$ & \\
\hline $1-2$ & $-1.54(.58)^{*}$ & $1-2$ & $-1.54(.58)^{*}$ \\
\hline $1-3$ & $-1.05(.62)$ & $1-3$ & $-1.05(.62)$ \\
\hline $2-2$ & $-.31(.30)$ & $2-2$ & $.04(.34)$ \\
\hline $2-3$ & $.52(.27) \dagger$ & $2-3$ & $.80(.36)^{*}$ \\
\hline $3-2$ & $.26(.23)$ & $3-2$ & $-.29(.33)$ \\
\hline $3-3$ & $-.02(.40)$ & $3-3$ & $-.39(.37)$ \\
\hline $\begin{array}{l}\text { Experimental } \\
\text { Condition (Rural) }\end{array}$ & & $\begin{array}{l}\text { Experimental } \\
\text { Condition (Rural) }\end{array}$ & \\
\hline $1-1$ & $.24(.53)$ & $1-1$ & $.24(.53)$ \\
\hline $2-1$ & $.08(.33)$ & $2-1$ & $.45(.36)$ \\
\hline $3-1$ & $.08(.33)$ & $3-1$ & $-.24(.43)$ \\
\hline $\begin{array}{l}\text { Experimental } \\
\text { Condition (Education) }\end{array}$ & & $\begin{array}{l}\text { Experimental } \\
\text { Condition (Education) }\end{array}$ & \\
\hline 1 - Some Primary School & $1.04(.51) \dagger$ & 1 - Some Primary School & $1.04(.52) \dagger$ \\
\hline $\begin{array}{l}1 \text { - Primary School } \\
\text { Complete }\end{array}$ & $.66(.48)$ & $\begin{array}{l}1 \text { - Primary School } \\
\text { Complete }\end{array}$ & $.66(.48)$ \\
\hline $\begin{array}{l}\text { 1- Intermediate to Post- } \\
\text { Secondary }\end{array}$ & $1.32(.46)^{* *}$ & $\begin{array}{l}\text { 1- Intermediate to Post- } \\
\text { Secondary }\end{array}$ & $1.32(.46)^{* *}$ \\
\hline 2 - Some Primary School & $-.48(.52)$ & 2 - Some Primary School & $.11(.45)$ \\
\hline $\begin{array}{l}2 \text { - Primary School } \\
\text { Complete }\end{array}$ & $-.46(.49)$ & $\begin{array}{l}2 \text { - Primary School } \\
\text { Complete }\end{array}$ & $-.32(.56)$ \\
\hline $\begin{array}{l}2 \text { - Intermediate to Post- } \\
\text { Secondary }\end{array}$ & $-.93(.54)$ & $\begin{array}{l}2 \text { - Intermediate to Post- } \\
\text { Secondary }\end{array}$ & $-.39(.42)$ \\
\hline 3 - Some Primary School & $.54(.41)$ & 3 - Some Primary School & $.28(.46)$ \\
\hline $\begin{array}{l}3 \text { - Primary School } \\
\text { Complete }\end{array}$ & $.39(.61)$ & $\begin{array}{l}3 \text { - Primary School } \\
\text { Complete }\end{array}$ & $.49(.53)$ \\
\hline $\begin{array}{l}3 \text { - Intermediate to Post- } \\
\text { Secondary }\end{array}$ & $.85(.52)$ & $\begin{array}{l}3 \text { - Intermediate to Post- } \\
\text { Secondary }\end{array}$ & $.71(.55)$ \\
\hline
\end{tabular}




\begin{tabular}{|c|c|c|c|}
\hline $\begin{array}{l}\text { Experimental } \\
\text { Condition (MCA1d } \\
\text { Quartile) }\end{array}$ & & $\begin{array}{l}\text { Experimental } \\
\text { Condition (MCA1d } \\
\text { Quartile) }\end{array}$ & \\
\hline $1-2$ & $-.55(.47)$ & $1-2$ & $-.55(.47)$ \\
\hline $1-3$ & $.05(.45)$ & $1-3$ & $.05(.45)$ \\
\hline $1-4$ & $-.14(.73)$ & $1-4$ & $-.14(.73)$ \\
\hline $2-2$ & $-.25(.41)$ & $2-2$ & $.03(.35)$ \\
\hline $2-3$ & $-.73(.42)$ & $2-3$ & $-.47(.42)$ \\
\hline $2-4$ & $-.48(.40)$ & $2-4$ & $-.36(.25)$ \\
\hline $3-2$ & $-.48(.33)$ & $3-2$ & $-.42(.43)$ \\
\hline $3-3$ & $-.34(.30)$ & $3-3$ & $-.31(.31)$ \\
\hline $3-4$ & $-.90(.30)^{* *}$ & $3-4$ & $-.78(.46)$ \\
\hline $\begin{array}{l}\text { Experimental } \\
\text { Condition (Age Groups) }\end{array}$ & & $\begin{array}{l}\text { Experimental } \\
\text { Condition (Age Groups) }\end{array}$ & \\
\hline $1-2$ & $.32(.61)$ & $1-2$ & $.32(.61)$ \\
\hline $1-3$ & $.63(.52)$ & $1-3$ & $.63(.51)$ \\
\hline $1-4$ & $1.41(.71) \dagger$ & $1-4$ & $1.41(.71) \dagger$ \\
\hline $2-2$ & $.90(.34)^{*}$ & $2-2$ & $.76(.45)$ \\
\hline $2-3$ & $.19(.32)$ & $2-3$ & $.71(.38) \dagger$ \\
\hline $2-4$ & $.30(.30)$ & $2-4$ & $.18(.33)$ \\
\hline $3-2$ & $.42(.46)$ & $3-2$ & $.37(.20) \dagger$ \\
\hline $3-3$ & $.10(.58)$ & $3-3$ & $-.04(.29)$ \\
\hline $3-4$ & $.26(.51)$ & $3-4$ & $.39(.30)$ \\
\hline /cut1 & $-2.63(.73)^{* *}$ & /cut1 & $-2.64(.74)^{* *}$ \\
\hline /cut2 & $-2.18(.74)^{* *}$ & /cut2 & $-2.18(.74)^{* *}$ \\
\hline /cut3 & $-1.42(.75) \dagger$ & /cut3 & $-1.43(.74) \dagger$ \\
\hline $\mathrm{N}$ & 1,334 & $\mathrm{~N}$ & 1,334 \\
\hline Population Size & $5,190,307$ & Population Size & $5,190,307$ \\
\hline Design DF & 19 & Design DF & 19 \\
\hline Number of Strata & 3 & Number of Strata & 3 \\
\hline Number of PSUs & 22 & Number of PSUs & 22 \\
\hline Number of Poststrata & 147 & Number of Poststrata & 147 \\
\hline Adjusted Wald Test (F) & & Adjusted Wald Test (F) & \\
\hline
\end{tabular}




\begin{tabular}{|l|l|l|l|}
\hline $\begin{array}{l}\text { Female MP-Female TA (2- } \\
3)\end{array}$ & $F(1,19)=2.68$ & $\begin{array}{l}\text { Female MP-Female TA }(2- \\
3)\end{array}$ & $F(1,19)=.08$ \\
\hline
\end{tabular}

${ }^{* * *} \mathrm{p}<.001,{ }^{* *} \mathrm{p}<.01,{ }^{*} \mathrm{p}<.05, \dagger \mathrm{p}<.10$. Standard errors in parentheses.

Figure A2.1. Predicted probability, men

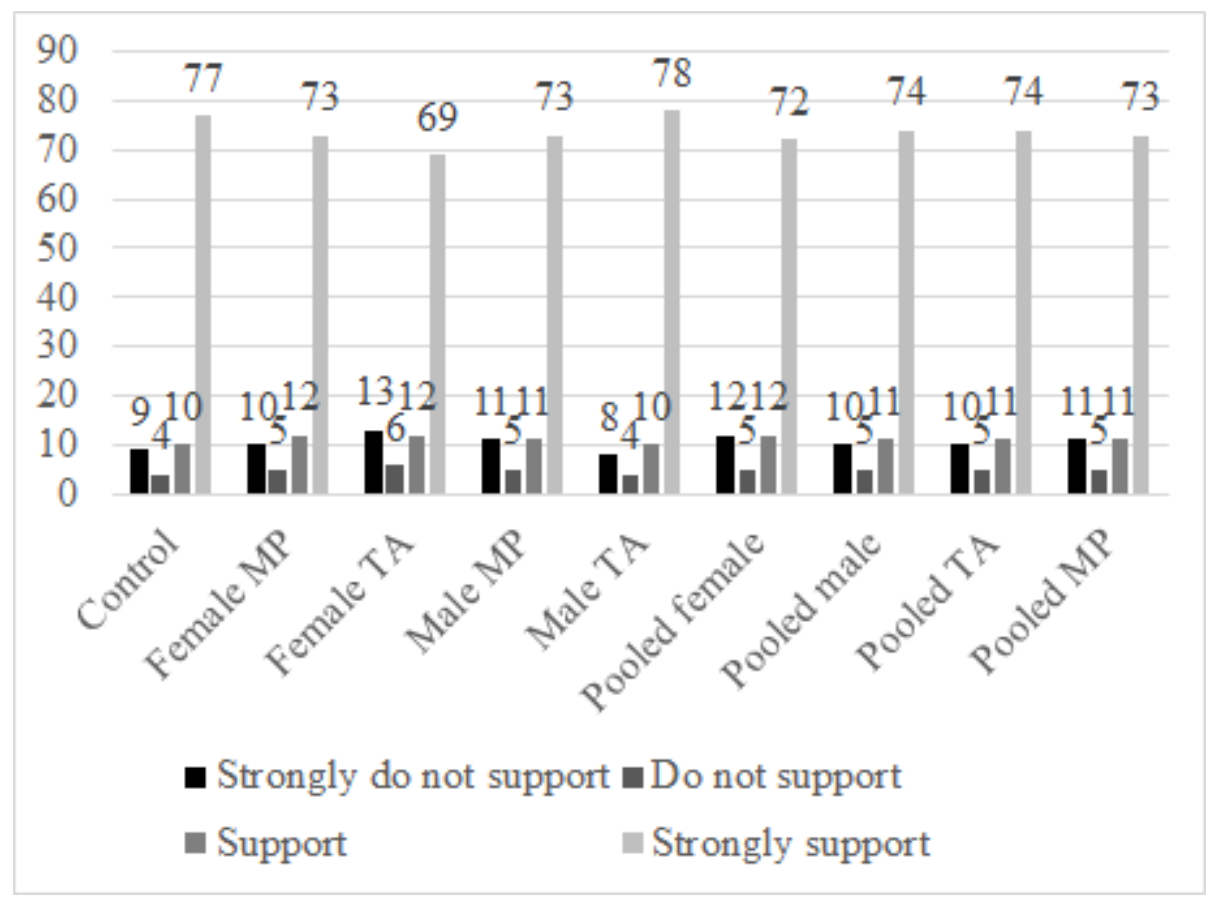

Table A2.3. Significance levels for pairwise comparisons (male)

\begin{tabular}{|c|c|c|c|c|}
\hline & Strongly do not support & Do not support & Support & Strongly support \\
\hline \multicolumn{5}{|c|}{ Comparisons of treatments with control } \\
\hline Female MP vs. control (2 vs. 1) & .475 & .368 & .284 & .381 \\
\hline Female TA vs. control (3 vs. 1) & .197 & .193 & .221 & .174 \\
\hline Male MP vs. control (4 vs. 1 ) & .202 & .400 & .844 & .352 \\
\hline
\end{tabular}




\begin{tabular}{|c|c|c|c|c|}
\hline Male TA vs. control (5 vs. 1 ) & .908 & .800 & .728 & .828 \\
\hline \multicolumn{5}{|c|}{ Comparisons of institutions (State vs. traditional) } \\
\hline Female TA vs. MP (3 vs. 2) & .429 & .571 & .783 & .514 \\
\hline Male TA vs. MP (5 vs. 4) & .345 & .362 & .574 & .375 \\
\hline \multicolumn{5}{|c|}{ Comparisons of gender (Female vs. male) } \\
\hline Male vs. female MP (4 vs. 2) & .707 & .937 & .391 & .971 \\
\hline Male vs. female TA (5 vs. 3 ) & .287 & .239 & .233 & .249 \\
\hline \multicolumn{5}{|l|}{ Other comparisons } \\
\hline Male TA vs. female MP (5 vs. 2) & .414 & .219 & .166 & .273 \\
\hline Male MP vs. female TA (4 vs. 3 ) & .592 & .466 & .293 & .467 \\
\hline \multicolumn{5}{|l|}{ Pooled comparisons (Gender) } \\
\hline Female vs. control (2 vs. 1 ) & .287 & .191 & .148 & .206 \\
\hline Male vs. control (3 vs. 1) & .517 & .484 & .463 & .483 \\
\hline Male vs. female (3 vs. 2) & .675 & .633 & .563 & .634 \\
\hline \multicolumn{5}{|l|}{ Pooled comparisons (Institution) } \\
\hline TA vs. control (2 vs. 1 ) & .210 & .130 & .136 & .148 \\
\hline MP vs. control (3 vs. 1) & $.060 \dagger$ & $.076 \dagger$ & $.058 \dagger$ & $.046^{*}$ \\
\hline MP vs. TA (3 vs. 2) & .883 & .864 & .923 & .888 \\
\hline
\end{tabular}

$* * * \mathrm{p}<.001,{ }^{* *} \mathrm{p}<.01,{ }^{*} \mathrm{p}<.05, \dagger \mathrm{p}<.10$. 